\title{
Evaluation of Platinum Group Elements (PGE) Potentials of Ultramafic Rocks of the Paleoproterozoic Nyong Series, Southeast Cameroon
}

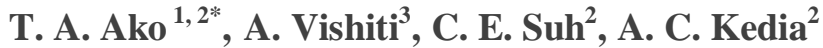 \\ ${ }^{I}$ Department of Geology, Federal University of Technology, Minna, Nigeria \\ ${ }^{2}$ Department of Geology, University of Buea, Cameroon \\ ${ }^{3}$ Department of Mining and Extractive Metallurgy, Institute of Science, Engineering and Technology, Cameroon \\ Christian University, Bali, Cameroon
}

\author{
*Corresponding Author: T. A. Ako, Department of Geology, Federal University of Technology, Minna, \\ Nigeria
}

\begin{abstract}
Meta-ultramafic rocks from the Paleoproterozoic Nyong Series (SE Cameroon) were investigated in this study. The aim was to study the petrology and evaluate the platinum group elements (PGEs) potentials of these rocks. A layered sequence exposed on a cliff face was mapped. Samples from the various horizons were collected and subsequently analysed in the laboratory for their petrographic and whole rock chemical compositions (but only the results of major oxides, $\mathrm{Ni}, \mathrm{Cu}, \mathrm{Au}$ and PGEs are presented in this study). The major element composition of the samples, determined by X-ray fluorescence $(X R F)$, indicate that the protolith is ultramafic in nature with $\mathrm{SiO} 2$ and $\mathrm{MgO}$ contents that range from 38.62 to $44.22 \mathrm{wt} \%$ and 21.56 to 35.21 wt \%, respectively. Gold (Au), copper (Cu), nickel (Ni) and $\Sigma P G E s$ contents in the samples range from 1.3 - $517.7 \mathrm{ppb}, 0.69-50 \mathrm{ppm}, 680-2622 \mathrm{ppm}$ and 5 - 11 ppm respectively. The principal PGEs identified by a combination of Ni sulphide fire assay, ICP-MS and instrumental neutron activation analysis (INAA) in these rocks are iridium (Ir, <1 to $7 \mathrm{ppb}$ ), palladium (Pd, 3 to $5 \mathrm{ppb})$ and platinum (Pt, <3 to 8 $p p b)$. The effect of alteration of the rocks has resulted in the low PGE concentration due to remobilization. It is also suggested that the rocks are PGE-depleted due to low degree of partial melting or depleted mantle source. It is however, not clear what the chemical composition of the layer beneath the studied samples is. Such data may be very useful in judging the PGE potential of the region.
\end{abstract}

Keywords: Platinum group elements, ultramafic rocks, Nyong Series, Southeast Cameroon, europium anomalies, depleted mantle source

\section{INTRODUCTION}

Ultramafic rocks are igneous and meta-igneous rocks with very low silica $(<45 \%)$ and $\mathrm{K}_{2} \mathrm{O}(<1 \%)$ contents, generally greater than $18 \% \mathrm{MgO}$, high $\mathrm{FeO}(>9 \%)$ and are composed of usually $>90 \%$ mafic minerals (dark coloured minerals with high magnesium and iron contents). Ultramafic rocks are often found in large intrusions where differentiated rock types commonly occur in layers (Ballhaus and Ryan, 1995, Maier et al., 2015, Barnes et al., 2015; Randive et al., 2015). Examples of these rocks include pyroxenite, peridotite, hornblendite, anorthosite, dunite, gabbro and norite.

A strong argument for a genetic relationship between magmas and mineral deposits is the observed consistent association that can be rationalized on the basis of magma crystallization (Maier et al., 2008, Power et al., 2004; Barnes et al., 2006; Hutchinson and McDonald, 2008 and Campos-Alvarez et al., 2012). Deposits of iron, copper, nickel, chromium, titanium and platinum-group elements (PGEs) are restricted to mafic and ultramafic rocks which also show markedly higher concentrations of these elements compared to more siliceous varieties. In addition, deposits of some of these metals characteristically occur in particular kinds of mafic and ultramafic rocks; e.g. chromium in dunite and peridotite, nickel in peridotite and norite and titanium in gabbro and anorthosite (Crocket and Paul, 2004, Maier et al., 2015). Because of the small quantity of dissolved water, crystallization of mafic and ultramafic magmas seldom leads to the generation of large amounts of ore-forming fluids, except 
perhaps when substantial assimilation of water-bearing crustal rocks are involved. It is well known that ortho magmatic processes scavenge PGEs and other chalcophile elements ( $\mathrm{Ag}, \mathrm{As}, \mathrm{Au}, \mathrm{Bi}, \mathrm{Cd}$, $\mathrm{Co}, \mathrm{Mo}, \mathrm{Ni}, \mathrm{Pb}, \mathrm{Re}, \mathrm{Sb}, \mathrm{Se}, \mathrm{Te}$ and $\mathrm{Zn}$ ) and form chromite, nickel, copper sulphides and PGE sulphide ore deposits (Naldrett, 2004; Dare et al., 2010; Maier et al., 2008; Godel et al., 2007; Maier et al., 2010). The PGE abundances in crustal rocks that have formed from silicate melts and magmatic volatile phases, are widely studied to identify the fundamental geochemical controls of their formation and distribution in earth's crust and to understand the characteristics of primary mantle magmatic processes (Momme et al., 2002, 2003; Crocket and Paul, 2004; Qi and Zhou, 2008; Song et al., 2009; Keays and Lightfoot, 2010; Mondal, 2011; Balaram et al., 2013; Maier et al., 2013). Platinum group element geochemistry can also be used to understand the mechanisms responsible for the $\mathrm{Ni}$ - $\mathrm{Cu}$ and PGE deposits in different geological and tectonic settings (Li and Ripley, 2009; Naldrett, 2010; Li et al., 2011; Balaram et al., 2013, Randive et al., 2015). This is the central theme of this research.

\section{Regional Gelogical SETTING}

The Nyong Series lies within the West Central African Belt (WCAB) (Figure 1) which is a N-Strending Paleoproterozoic belt that extends along the western side of the Congo craton from Angola to Cameroon (Feybesse et al., 1998), and continues to NE Brazil as the Transamazonia belt (Penaye et al., 2004; Lerouge et al., 2006; Owona, 2008; Owona et al., 2011 and Owona et al., 2013). The WCAB includes the Nyong complex in Cameroon known as the lower Nyong Unit (Maurizot et al., 1986); the Franceville-Ogoue complex in Gabon and the West Congolese complex in the Republic of Congo and Democratic Republic of Congo (Bonhomme et al., 1982; Feybesse et al., 1998; Vitcat and Pouclet, 2000; Tack et al., 2001).

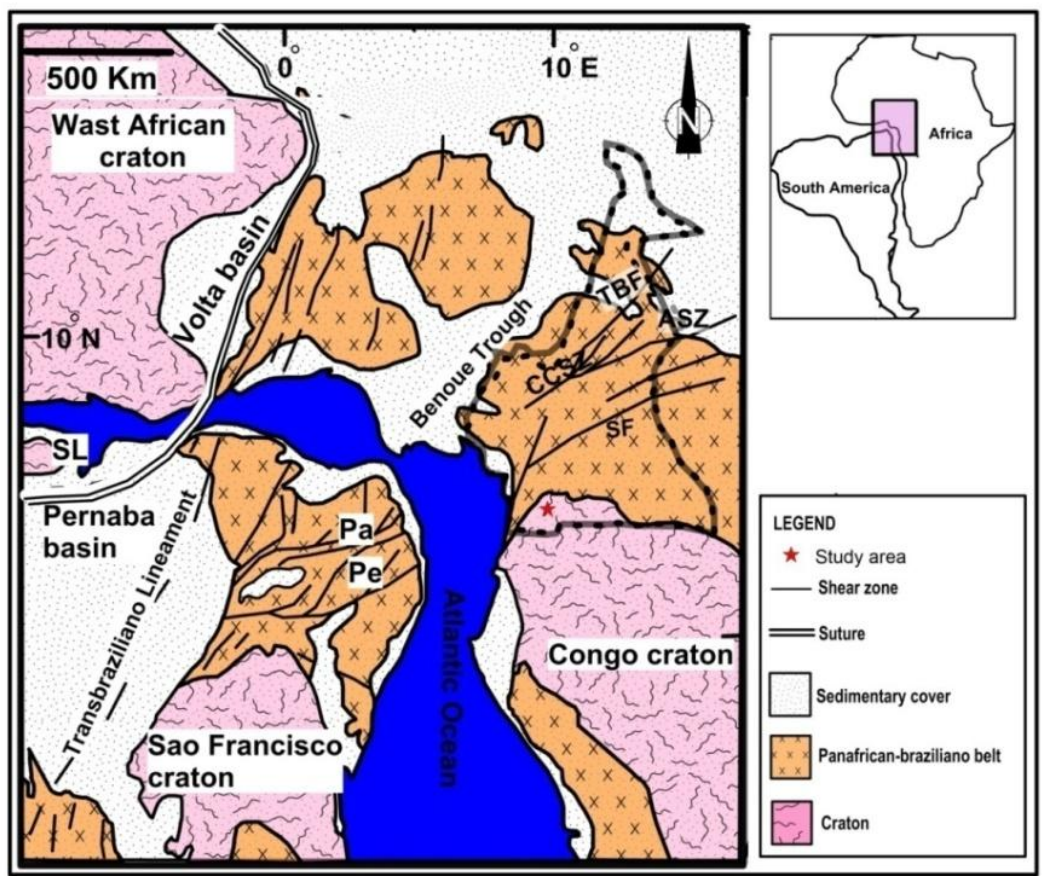

Figure1. Geological map of the pre-drift Gondwana showing the Congo craton in Cameroon and the northern part of São Francisco craton of Brazil (modified after Ebah Abeng et al., 2012).

This large belt resulted from the collision between the Congo and São Francisco cratons. Most of the WCAB is characterized by tectonic reworking of Archean crust with little addition of juvenile material, particularly in the southern part of the belt (Thomas et al., 2002; Toteu et al., 1994a). However, this dominant recycling character is diminished northward with the appearance of $\sim 2.1 \mathrm{Ga}$ juvenile metasedimentary and meta-plutonic rocks intensively reworked and dismembered in the Pan-African belt north of the Congo craton (Pénaye et al., 2004). The Nyong Series (coined as Nyong Group, e.g. Lerouge et al., 2006; Owona, 2008; Owona et al., 2011; Owona et al., 2013) in the northwestern corner of the Congo craton in Cameroon is a-well-preserved granulitic unit of the WCAB resting as an Eburnean nappe on the Congo craton (Feybesse et al., 1986; Toteu et al., 1994b). The high-grade metamorphism associated with arrested charnockite formation in this unit is 
dated at $2050 \mathrm{Ma}$ (Toteu et al., 1994b); Lerouge et al., 2006). However, it is not clear whether or not these Paleoproterozoic tectono-metamorphic events were accompanied by any sedimentation or magmatism. This led to the assertion that the Nyong Series is a reworked part of the Congo craton in Cameroon (Lasserre and Soba, 1976; Faybesse et al., 1986; Owona, 2008, Owona et al., 2011; Owona et al., 2013). Within the Cameroon context the series has been called the Nyong Unit by some authors (e.g. Ebah Abeng et al., 2012). The Nyong Unit is bordered by the Ntem Unit in the SE, the PanAfrican gneiss to the north and NE and by the Quaternary sedimentary formations (Kribi Campo basin) at the NW parts (Figure 2).

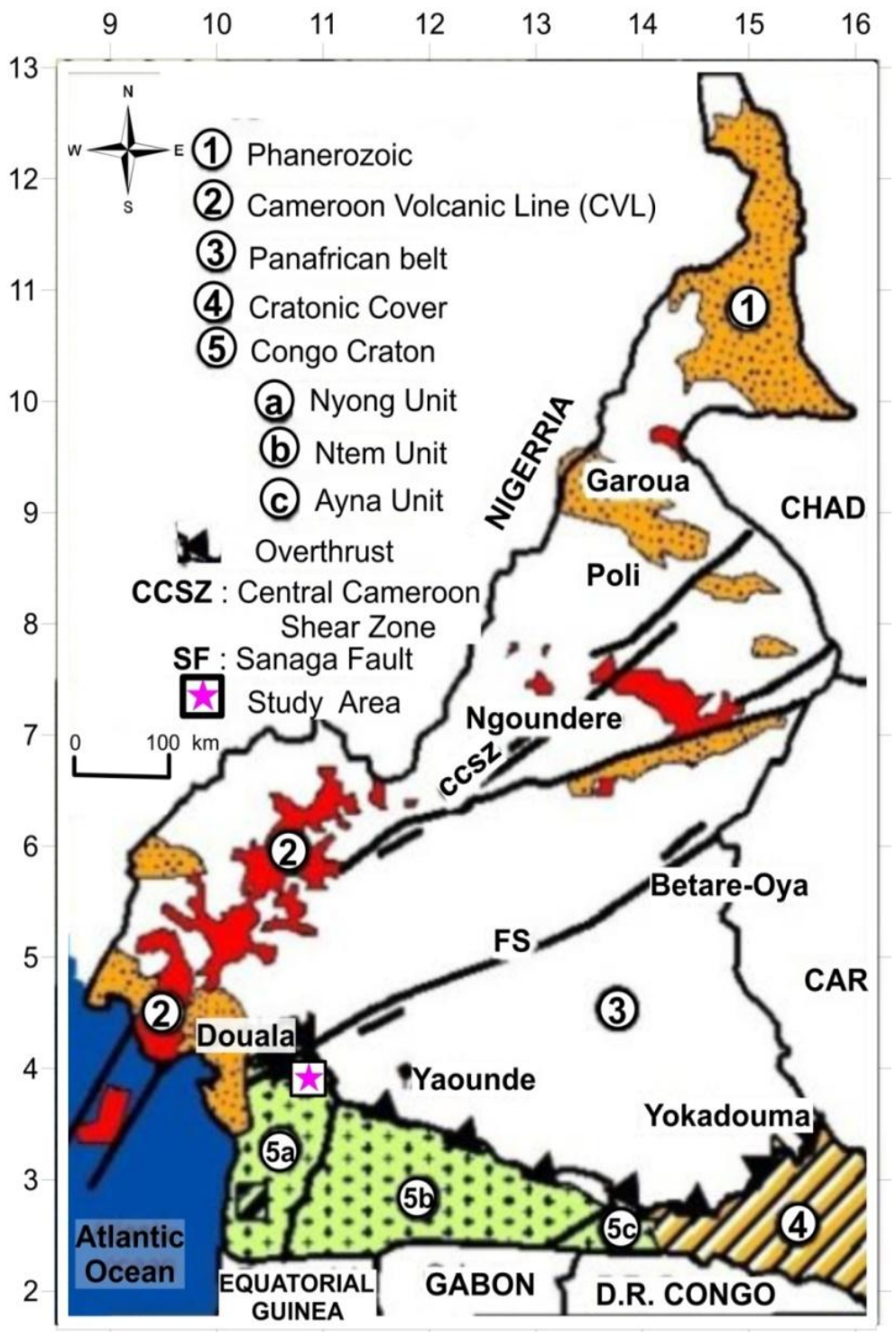

Figure2. Geological map of Cameroon showing the relationship between the Nyong Unit (study area), Ntem Unit, Pan-African gnesises and the Quaternary sedimentary formations (modified after Ebah Abeng et al., 2012).

It is a high grade-gneiss unit, which was initially defined as a Neoproterozoic, or a Palaeoproterozoic reactivated NW corner of the Archaean Congo Craton (Lasserre and Soba, 1976; Feybesse et al., 1986, Lerouge et al., 2006). The Nyong Unit is made up of a greenstone belt (pyroxenites, amphibolopyroxenites, peridotites, talcschists, amphibolites and banded iron formations), foliated series (Tonalite - Trondhjemite - Granodiorite (TTG), gneiss), and magmatic rocks (augen metadiorites, granodiorites and synites) (Lerouge et al., 2006; Owona et al., 2013; Ndema Mbongue et al., 2015). The late magmatic rocks are represented by SW-NE-trending group of small intrusions extending from Lolodorf to Olama and N-S from Lolodorf to Ngog-Tos and Edea (Ebah Abeng et al., 2012, Ako et al., 2015) (Figure 3) while the surrounding formations of greenstone belt are made up of gneiss and TTG. 
The Nyong Unit is characterized by a regional flat-lying S1/S2 foliation associated with a variably oriented stretching lineation and local large open folds associated with N-S sinistral strike slip faults (Lerouge et al., 2006). The metamorphic evolution is polycyclic with Paleaoproterozoic granulitic assemblages overprinted in the western part of the unit by Pan-African high-grade recystallizations (Toteu et al., 1994a). The unit is a Paleaoproterozoic unit characterized by pre-orogenic sediments $(<\mathrm{ca} .2500 \mathrm{Ma})$ and is interpreted as an allochtnous unit thrusted on to the Congo craton during the Eburnean-Transamazonian orogeny (Lerouge et al., 2006). This nappe tectonic event is the ultimate stage of a complete Paleaoproterozoic orogenic cycle whose major characteristics, including the suture zone, are preserved in NE Brazil (Lerouge et al., 2006).

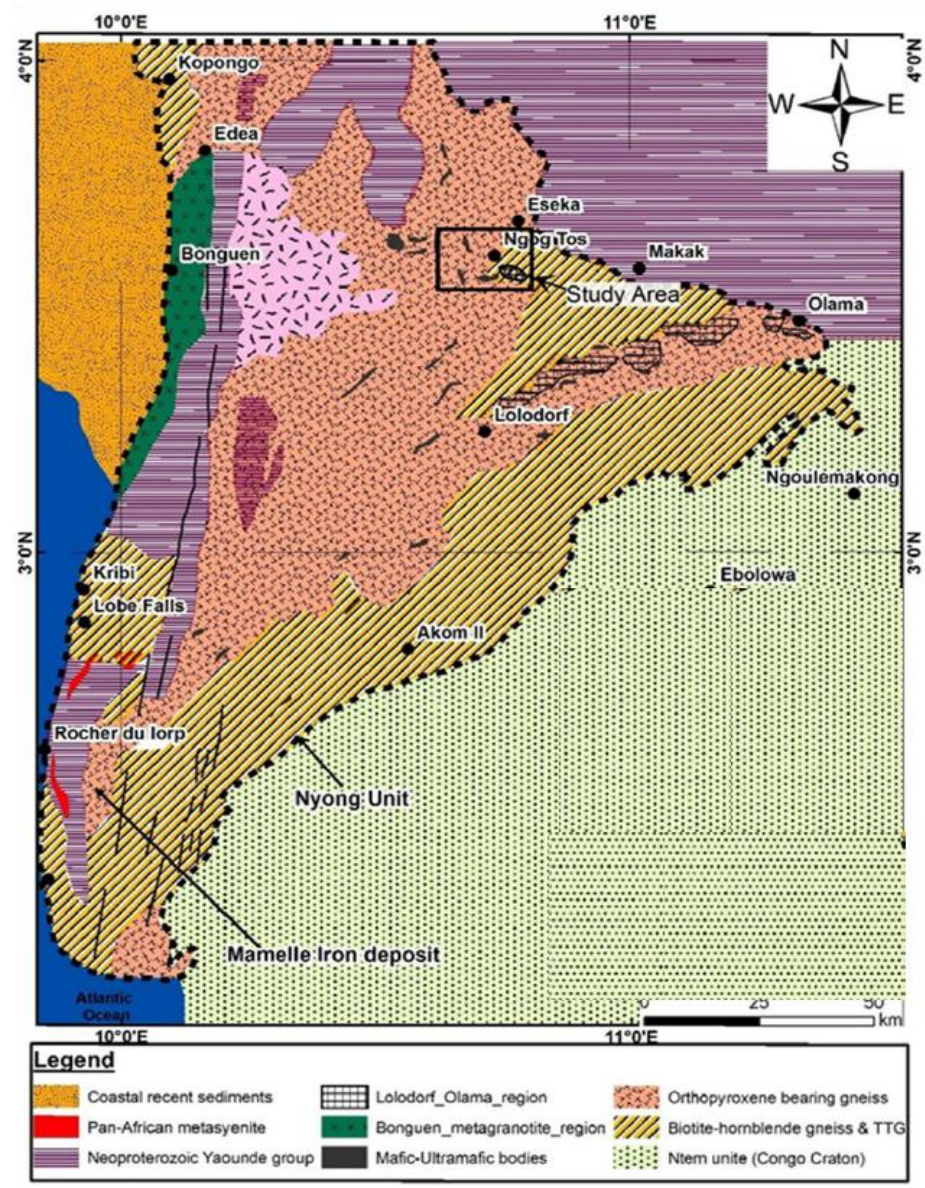

Figure3. Geological map showing the late magmatic rocks that intruded the country rocks within the Nyong Series (modified after Lerouge et al., 2006; Ebah Abeng et al., 2012). Study area indicated not to scale.

\section{Materials AND MethodS}

The field study consisted of systematic mapping and sampling of lithological units of the selected area within the Nyong Series where ultramafic rocks where found. A total of twenty seven ultramafic rock samples were collected during the field work and were later used for the various analyses. Preparation of the polished thin sections was done at the University of Ghent, Belgium and studied in the laboratory of the Department of Geology, University of Buea, Cameroon. Details of these are contained in Ako et al., 2015.

Twenty seven metamorphosed ultramafic rock samples were crushed using a jaw crusher with steel plates. The crushed samples were pulverized in a ball mill made up of $99.8 \% \mathrm{Al}_{2} \mathrm{O}_{3}$ at the $\mathrm{ACME}$ Analytical Laboratory, Vancouver, Canada. A two-step loss on ignition (LOI) was done in which powders were first heated at $105^{\circ} \mathrm{C}$ in the presence of nitrogen to drive off adsorbed water and then ignited at $1000^{\circ} \mathrm{C}$ in the presence of oxygen to drive off the remaining volatile components.

Major and some minor element concentrations were determined by X-ray fluorescence (XRF). About $0.2 \mathrm{~g}$ of powdered samples were first ignited and then melted with lithium tetraborate flux and digested with nitric acid before analysis using a wavelength-dispersive X-ray fluorescence 
spectrometer (Acme lab method code 4A). In addition, a separate $0.5 \mathrm{~g}$ split/sub-sample was digested in aqua regia and analysed by inductively coupled plasma mass spectrometry (ICP-MS) to report the precious and base metals (method codes $4 \mathrm{~B}$ and 1DX). In this method, the split samples were treated in a mixture of $\mathrm{HCl}$ and $\mathrm{HClO}_{4}$ at $120^{\circ} \mathrm{C}$ in sealed beakers for one week, after which they were rinsed out of the containers with dilute $\mathrm{HNO}_{3}$ and dried. The resulting residues were redissolved in $\mathrm{HCl}$ and $\mathrm{HClO}$ mixture and evaporated to dryness again and finally redissolved in a mixture of $\mathrm{HNO}_{3}, \mathrm{HCl}$ and $\mathrm{HF}$ at $100^{\circ} \mathrm{C}$. The sample solutions produced were then analysed. The detection limits for the major oxides is 0.01 except $\mathrm{MgO}$ and $\mathrm{Cr}_{2} \mathrm{O}_{3}$ which had detection limits of 0.04 and 0.002 wt $\%$ respectively while the trace elements had detection limits ranging from $0.01-8 \mathrm{ppm}$.

Gold $(\mathrm{Au})$, platinum $(\mathrm{Pt})$ and palladium $(\mathrm{Pd})$ were analysed by Ni sulphide fire assay method (code 3B-MS). A $25 \mathrm{~g}$ aliquot of each sample was fused at $1000^{\circ} \mathrm{C}$ with a suitable amount of flux for the sample matrix with nickel oxide and sulphur added as a carrier. The resulting nickel sulphide button was extracted, ground and partially dissolved in $1 \mathrm{MHCl}$ under a high enough $\mathrm{f}_{\mathrm{H} 2 \mathrm{~S}}$ to ensure that the precious metals remain insoluble. The resulting insoluble residues containing the precious metals was dissolved in aqua regia and analysed by ICP-MS. Au, Pt and Pd had detection limits of 2, 3 and $2 \mathrm{ppb}$ respectively.

The remaining PGEs (Ir, Os, Rh and Ru) were determined by nickel-sulphide fire assay followed by Te co-precipitation (code NAA-2). The sample solutions were melted with sodium carbonate and sodium tetraborate in the presence of nickel sulfide melt. After the quenching of each sample, a bead of $\mathrm{NiS}$ was broken out of the crucible and digested by concentrated $\mathrm{HCl}$ in Telfon vessels using concentrated $\mathrm{HCl}$ acid. Tellurium co-precipitation was used to ensure that the insoluble residue to acid digestion retained all Au-PGE. Solutions were filtered in a vacuum after which the precipitate was redissovled in aqua regia and deionized water. The resulting solutions were analysed by instrumental neutron activation analysis (INAA). Details of this method are contained in Savard et al. (2010). The detection limits for Ir, Os, Rh and Ru was 1, 10, 5 and $50 \mathrm{ppb}$ respectively. All the analyses were done at Acme Analytical Laboratory, Vancouver, Canada. The accuracy of the analytical results was verified through the analysis of matrix-matched reference materials, and any potential contamination during sample preparation and analysis was monitored via suitable black materials. All analytical data presented in this work passed through quality control tests to ascertain the reliability of the results.

\section{RESUlts}

\subsection{Field Characteristics of the Ultramafic Rocks}

The study area is made up of two distinct rock units. These units are the metasedimentary unit which is represented by the talc-tremolite schists and these rocks occur as floats of blocks with fine to medium-grained texture a meta-igneous unit which is made up of amphibole-pyroxene gneiss, amphibole-garnet gneiss and biotite-garnet gneiss. These units have been intruded by ultramafic rocks which were sampled for this study. The ultramafic unit investigated is a layered sequence exposed on a cliff face and details of the geology and petrography are contained in Ako et al., 2015 and depicted in Figure 4.

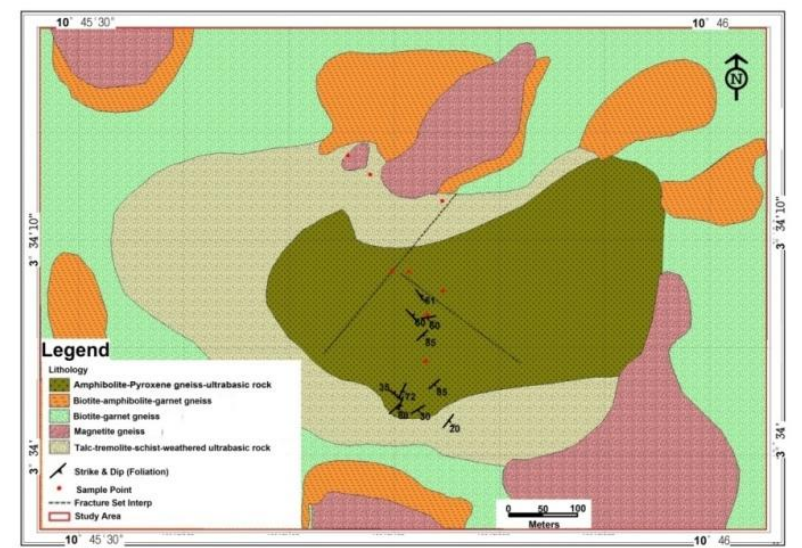

Figure4. Geological map of the study area showing the various lithologies intruded by the ultramafic rocks (after Ako et al., 2015). 
Evaluation of Platinum Group Elements (PGE) Potentials of Ultramafic Rocks of the Paleoproterozoic Nyong Series, Southeast Cameroon

\subsection{Whole-rock Geochemistry}

The major and Ni-Cu-Au- PGE data of the ultramafic rocks of the study area are presented in tables 1and 2. Variable amounts of loss on ignition (LOI) mainly reflect variable degrees of alteration of the rock samples.

The ultramafic rock samples from in the northern part of the Nyong Series (study area) are characterized by high values of $\mathrm{SiO}_{2}$ that range from 38.62 and $43.22 \mathrm{wt} \%$ with an average of 40.80 wt $\%$ and $\mathrm{MgO}$ values that range from 21.56 to $35.21 \mathrm{wt} \%$ with an average of $32.81 \mathrm{wt} \%$ (Table 1 ). The concentration of $\mathrm{Fe}_{2} \mathrm{O}_{3} \mathrm{t}$ in the samples is moderate with a range of 6.67-16.7 wt \% and an average of $10.61 \mathrm{wt} \% . \mathrm{Al}_{2} \mathrm{O}_{3}$ values in the samples are very low $(1.67-2.99 \mathrm{wt} \%)$ with an average of $\sim 2.5$ wt $\%$ but sample ESK 27 again shows a higher value of 8.27 wt \%. Calcium oxide concentration in the samples is much less $(<0.01$ to 1.14 wt \% except sample ESK 27 which has a $\mathrm{CaO}$ concentration of $5.17 \mathrm{wt} \%$. The samples are equally poor in alkalies $\left(\mathrm{Na}_{2} \mathrm{O}\right.$ and $\left.\mathrm{K}_{2} \mathrm{O}\right), \mathrm{TiO}_{2}, \mathrm{MnO}$ and $\mathrm{P}_{2} \mathrm{O}_{5} . \mathrm{Na}_{2} \mathrm{O}$, $\mathrm{K}_{2} \mathrm{O}, \mathrm{TiO}_{2}, \mathrm{MnO}$ and $\mathrm{P}_{2} \mathrm{O}_{5}$ values in the samples have ranges of 0.03-0.04 wt \%, $0.01-0.04 \mathrm{wt} \%$, $0.05-0.6 \mathrm{wt} \%, 0.08-0.25 \mathrm{wt} \%$ and $0.01-0.03 \mathrm{wt} \%$, respectively. These values are extremely very low and do not exceed $0.6 \mathrm{wt} \%$ (Table 1 ).

Bulk composition/whole rock analyses indicate that the magma type is calc-alkaline in nature but trending towards tholeiitic as supported by AFM diagram (Irvine and Baragar, 1975) (Figure 5a), while according to TAS plot by Cox et al. (1979) the rocks are utrabasic with alkaline to subalkaline/ tholeiitic character (Figure 5b). A classification of the rocks using the models by Middlemost (1985) and De La Roche et al., (1980) reveals that the primary rocks are peridotite-gabbro and gabbro norite (Figure 6a and b).

Table1. Major element contents (wt. \%) of the ultramafic rocks in the Nyong Series

\begin{tabular}{|c|c|c|c|c|c|c|c|c|c|c|c|c|c|c|c|}
\hline $\begin{array}{l}\text { Sample } \\
\text { No. } \rightarrow\end{array}$ & & $\begin{array}{c}\text { ESK } \\
1\end{array}$ & \begin{tabular}{|c|} 
ESK \\
2 \\
\end{tabular} & ESK 3 & $\begin{array}{c}\text { ESK } \\
4\end{array}$ & ESK 5 & $\begin{array}{c}\text { ESK } \\
6\end{array}$ & $\begin{array}{c}\text { ESK } \\
7\end{array}$ & \begin{tabular}{|c|} 
ESK \\
8 \\
\end{tabular} & ESK 9 & $\begin{array}{c}\text { ESK } \\
10\end{array}$ & $\begin{array}{c}\text { ESK } \\
11\end{array}$ & $\begin{array}{c}\text { ESK } \\
12\end{array}$ & $\begin{array}{c}\text { ESK } \\
13\end{array}$ & $\begin{array}{c}\text { ESK } \\
14\end{array}$ \\
\hline Major Oxide & d.l & & & & & & & & & & & & & & \\
\hline $\mathrm{SiO}_{2}$ & 0.01 & 40.59 & 40.58 & 40.41 & 40.39 & 41.04 & 41.32 & 1.41 & 41.33 & 39.82 & 39.81 & 39.88 & 39.85 & 1.28 & 11.24 \\
\hline $\mathrm{Al}_{2} \mathrm{O}_{3}$ & 0.01 & 2.22 & 2.31 & 2.98 & 2.97 & 1.95 & 1.96 & 1.79 & 1.76 & 1.69 & 1.67 & 1.86 & 1.82 & .13 & .15 \\
\hline $\mathrm{e}_{2} \mathrm{O}_{3}$ & 0.01 & 12.51 & 12.44 & 11.36 & 11.39 & 11.01 & 11.1 & 10.08 & 10.09 & 11.17 & 11.21 & 9.97 & 9.96 & .00 & 9.02 \\
\hline $\mathrm{MgO}$ & 0.04 & 32.31 & 32.29 & 32.51 & 32.61 & 33.5 & 33.49 & 34.19 & 34.21 & 32.93 & 33.01 & 34.27 & 34.31 & 34.44 & 34.49 \\
\hline $\mathrm{aO}$ & 0.01 & 0.05 & 0.05 & 0.02 & 0.01 & $<0.01$ & $<0.01$ & 0.02 & 0.03 & 0.94 & 0.92 & 0.15 & 0.16 & 0.01 & 0.01 \\
\hline${ }_{2} \mathrm{O}$ & 0.01 & 0.04 & 0.03 & $<0.01$ & $<0.01$ & $<0.01$ & $<0.01$ & $<0.01$ & $<0.01$ & $<0.01$ & $<0.01$ & $<0.01$ & $<0.01$ & $<0.01$ & $<0.01$ \\
\hline${ }_{2} \mathrm{O}$ & 0.01 & 0.04 & 0.04 & 0.02 & 0.01 & $<0.01$ & $<0.01$ & $<0.01$ & $<0.01$ & $<0.01$ & $<0.01$ & $<0.01$ & $<0.01$ & $<0.01$ & $<0.01$ \\
\hline $\mathrm{TiO}_{2}$ & 0.01 & 0.09 & 0.08 & 0.11 & 0.13 & 0.07 & 0.06 & 0.07 & 0.06 & 0.06 & 0.07 & 0.05 & 0.05 & 0.08 & 0.07 \\
\hline $\mathrm{P}_{2} \mathrm{O}_{5}$ & 0.01 & $<0.01$ & $<0.01$ & 0.01 & 0.01 & $<0.01$ & $<0.01$ & 0.01 & 0.01 & 0.02 & 0.03 & $<0.01$ & $<0.01$ & $<0.01$ & $<0.01$ \\
\hline $\mathrm{MnO}$ & 0.01 & 0.11 & 0.12 & 0.16 & 0.15 & 0.1 & 0.11 & 0.11 & 0.12 & 0.12 & 0.12 & 0.1 & 0.10 & 0. & 0.11 \\
\hline $\mathrm{Cr}_{2} \mathrm{O}_{3}$ & 0.002 & 0.522 & 0.521 & 0.505 & 0.51 & 0.321 & 0.34 & 0.516 & 0.52 & 0.459 & 0.46 & 0.42 & 0.42 & 0.52 & 0.53 \\
\hline LOI & -5.1 & 10.8 & 10.7 & 11 & 10.98 & 11.1 & 11 & 11 & 10.9 & 11.9 & 11.81 & 12.40 & 12.30 & 11.50 & 11.50 \\
\hline TOTAL & & 99.28 & 99.16 & 99.085 & 99.16 & 99.111 & 99.38 & 99.196 & 99.03 & 99.109 & 99.11 & 99.11 & 98.97 & 99.06 & 99.12 \\
\hline
\end{tabular}

Table1 (continued)

\begin{tabular}{|c|c|c|c|c|c|c|c|c|c|c|c|c|c|c|}
\hline $\begin{array}{l}\text { Sample } \\
\text { No. } \rightarrow\end{array}$ & & ESK 15 & ESK 1 & ESK 1 & ESK 1 & ESK 19 & ESK 20 & ESK 21 & ESK 2 & ESK 23 & $3 \mid$ ESK 24 & 4 ESK 25 & ESK 2c & 6 ESK 27 \\
\hline $\begin{array}{l}\text { Major } \\
\text { Oxide } \\
\text { (wt. \%) } \\
\downarrow \\
\end{array}$ & d.1 & & & & & & & & & & & & & \\
\hline $\mathrm{SiO}_{2}$ & 0.01 & 41.35 & 41.34 & 43.10 & 43.11 & 43.21 & 43.22 & 39.61 & 39.59 & 38.63 & 38.62 & 40.59 & 40.57 & 39.45 \\
\hline $\mathrm{Al}_{2} \mathrm{O}_{3}$ & 0.01 & 2.36 & 2.40 & 1.84 & 1.83 & 1.9 & 1.91 & 2.16 & 2.14 & 2.55 & 2.53 & 1.84 & 1.86 & 8.27 \\
\hline $\mathrm{Fe}_{2} \mathrm{O}_{3}$ & 0.01 & 9.36 & 9.33 & 6.69 & 6.67 & 6.93 & 6.92 & 10.8 & 10.81 & 13.47 & 13.49 & 11.49 & 11.47 & 16.7 \\
\hline $\mathrm{MgO}$ & 0.04 & 34.00 & 34.01 & 35.21 & 35.19 & 34.97 & 34.96 & 32.78 & 32.76 & 31.97 & 31.9 & 33.43 & 33.41 & 21.56 \\
\hline $\mathrm{CaO}$ & 0.01 & 0.11 & 0.12 & 0.01 & 0.01 & $<0.01$ & $<0.01$ & 1.14 & 1.12 & 0.61 & 0.59 & 0.07 & 0.09 & 5.17 \\
\hline $\mathrm{Na}_{2} \mathrm{O}$ & 0.01 & $<0.01$ & $<0.01$ & $<0.01$ & $<0.01$ & $<0.01$ & $<0.01$ & $<0.01$ & $<0.01$ & $<0.01$ & $<0.01$ & $<0.01$ & $<0.01$ & $<0.01$ \\
\hline $\mathrm{K}_{2} \mathrm{O}$ & 0.01 & $<0.01$ & $<0.01$ & $<0.01$ & $<0.01$ & $<0.01$ & $<0.01$ & $<0.01$ & $<0.01$ & $<0.01$ & $<0.01$ & $<0.01$ & $<0.01$ & $<0.01$ \\
\hline $\mathrm{TiO}_{2}$ & 0.01 & 0.07 & 0.07 & 0.08 & 0.07 & 0.06 & 0.6 & 0.08 & 0.07 & 0.11 & 0.12 & 0.06 & 0.07 & 0.27 \\
\hline $\mathrm{P}_{2} \mathrm{O}_{5}$ & 0.01 & 0.01 & 0.01 & 0.02 & 0.02 & $<0.01$ & $<0.01$ & $<0.01$ & $<0.01$ & $<0.01$ & $<0.01$ & $<0.01$ & $<0.01$ & 0.03 \\
\hline $\mathrm{MnO}$ & 0.01 & 0.15 & 0.14 & 0.10 & 0.10 & 0.09 & 0.08 & 0.11 & 0.12 & 0.14 & 0.14 & 0.11 & 0.12 & 0.25 \\
\hline $\mathrm{Cr}_{2} \mathrm{O}_{3}$ & 0.002 & 0.53 & 0.53 & 0.41 & 0.40 & 0.537 & 0.529 & 0.456 & 0.46 & 0.519 & 0.521 & 0.541 & 0.554 & 0.301 \\
\hline LOI & -5.1 & 11.20 & 11.10 & 11.70 & 11.50 & 11.5 & 11.4 & 12 & 12.10 & 11.1 & 11.2 & 11 & 10.8 & 7.5 \\
\hline TOTAL & & 99.14 & 99.05 & 99.16 & 98.90 & 99.197 & 99.619 & 99.136 & 99.17 & 99.099 & 99.111 & 99.131 & 98.944 & 99.501 \\
\hline
\end{tabular}

d.l: detection limits 
Evaluation of Platinum Group Elements (PGE) Potentials of Ultramafic Rocks of the Paleoproterozoic Nyong Series, Southeast Cameroon
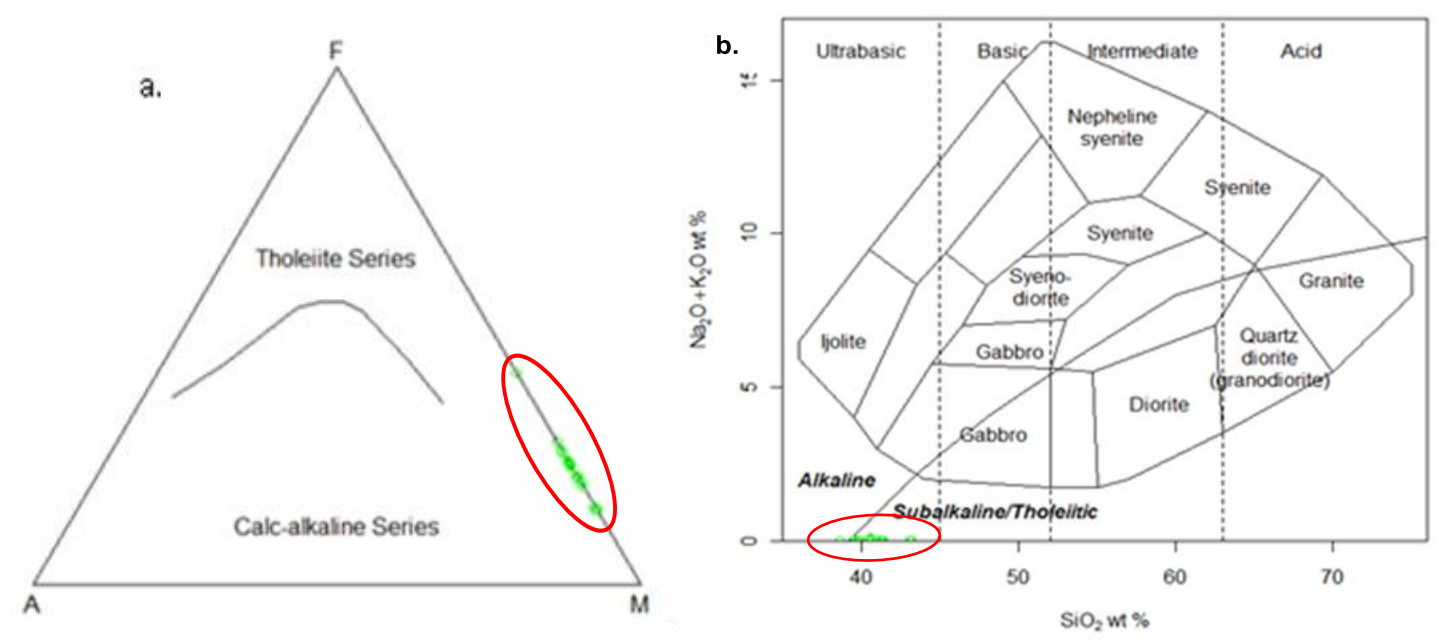

Figure5. Geochemical classification plots for the ultramafic rocks of the Nyong Series. (a) AFM diagram for the ultramafic rocks samples (after Irvine and Baragar, 1975) and (b) TAS diagram of the ultramafic rocks (after Cox et al., 1979).
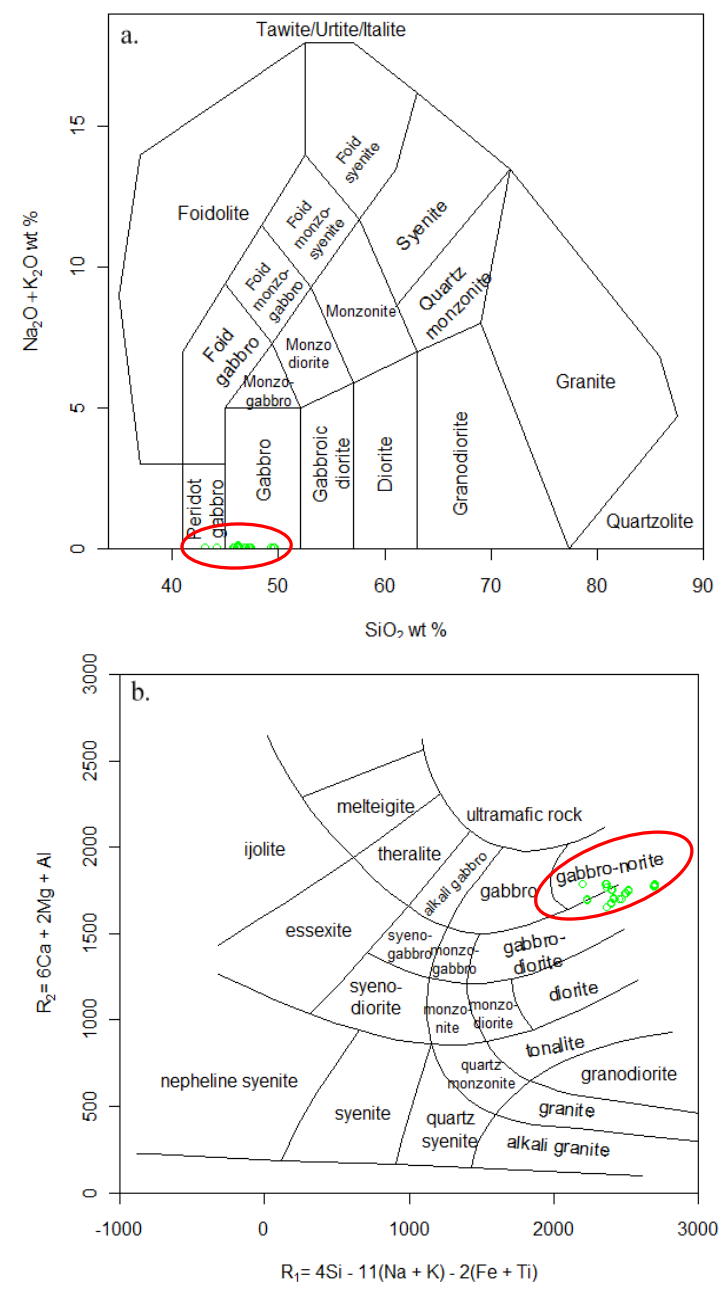

Figure6. Classification of the ultramafic rocks of the Nyong Series to reveal their primary rock types. a $\mathrm{Na}_{2} \mathrm{O}+$ $\mathrm{K}_{2} \mathrm{O}$ vs. $\mathrm{SiO}_{2}$ (after Middlemost, 1985). b R2=6Ca+2Mg+Alvs. $\mathrm{Rl}=4 \mathrm{Si}-11(\mathrm{Na}+\mathrm{K})-2(\mathrm{Fe}+\mathrm{Ti})($ after $\mathrm{De}$ La Roche et al., 1980)

A plot of the samples on a geotectonic diagram after Pearce et al. (1977) indicates that most of the samples cluster in the oceanic ridge and floor field except one sample that tends to plot on the boundary between oceanic ridge and floor and oceanic Island (Figure 7). This can be inferred that the tectonic environment of eruption of the primary rocks is oceanic ridge and floor, and oceanic island arc environment. 


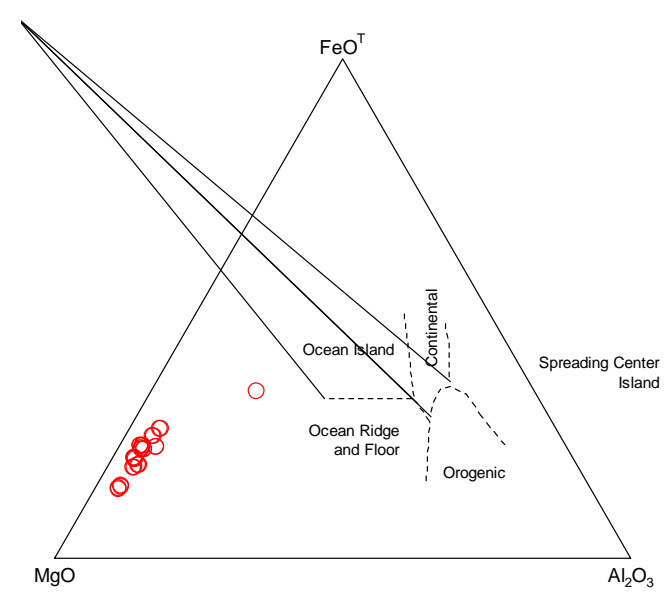

Figure7. Geotectonic classification of the ultramafic rock samples of the Nyong Series (after Pearce et al., 1977).

Bivariate plots of $\mathrm{MgO}$ against $\mathrm{SiO}_{2}, \mathrm{Al}_{2} \mathrm{O}_{3}, \mathrm{CaO}, \mathrm{Fe}_{2} \mathrm{O}_{3} \mathrm{t}, \mathrm{TiO}_{2}$ and $\mathrm{Na}_{2} \mathrm{O}+\mathrm{K}_{2} \mathrm{O}$ show a distinct linear regression (either positive or negative slope) for the ultramafics (Figure 8a - f). They tend to indicate an affinity towards fractional crystallization and their geochemical constituents correspond to very high $\mathrm{MgO}$ which is geochemically close to komatiite composition. This observation is similar to what has been reported from the Kabanga nickel sulphides (Maier et al. 2010), Mount Keith nickel deposit (Barnes et al, 2012) but different from the Lolodorf pyroxenites and amphibolites (Ebah Abeng et al. 2012), Pedre Dourada mafic rocks (Jordt-Evangelista,1996) and the Platreef magmatic sulphides (Ihlenfeld and Keays, 2011). The main study area lithologies are made up of a wide and continuous range of rocks varying from least altered pyroxenites over less altered varieties to more altered amphibolite.
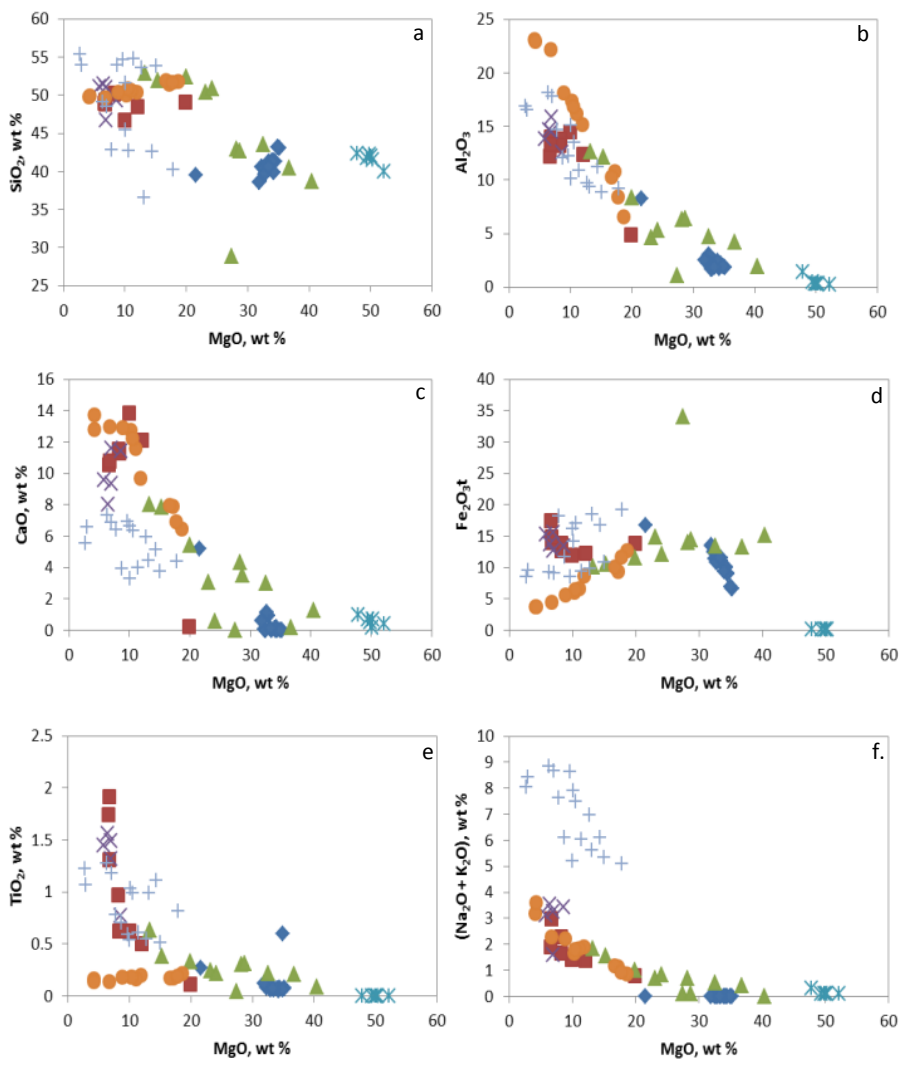

- This study

$\triangle$ Kabanga nickel sulfide deposits

- Lolodorf pyroxenites and amphibolites Pedre Dourada mafics - Platreef magmatic sulfides

Figure8. Comparison of whole-rock composition of the ultramafic rocks in the Nyong Series with similar studies in other parts of the world. (a) $\mathrm{Plot}_{\text {of }} \mathrm{SiO}_{2}$ vs $\mathrm{MgO}$. (b) $\mathrm{Al}_{2} \mathrm{O}_{3}$ vs $\mathrm{MgO}$. (c) $\mathrm{CaO}$ vs $\mathrm{SiO}_{2}$. (d) $\mathrm{Fe}_{2} \mathrm{O}_{3} \mathrm{t}$ vs $\mathrm{SiO}_{2}$. (e) $\mathrm{TiO}_{2}$ vs $\mathrm{SiO}_{2}$. (f) $\mathrm{Na}_{2} \mathrm{O}+\mathrm{K}_{2} \mathrm{O}$ vs $\mathrm{SiO}_{2}$ 
Evaluation of Platinum Group Elements (PGE) Potentials of Ultramafic Rocks of the Paleoproterozoic Nyong Series, Southeast Cameroon

The values of Ni-Cu-Au-PGE in the samples are presented in table 2. The ultramafic rocks of the northern limit of the Nyong Series show very low $\Sigma$ PGE contents with a very narrow range of $5-13$ ppb and $\Sigma$ Au-PGE concentrations from 7.7 to $521.7 \mathrm{ppb}$. Os, Rh and Ru were all below detection limits in the samples, thus only Pd, Pt and Ir were used for plotting and comparison in the study. Pd (3 to $5 \mathrm{ppb}$ ); Ir ( $<1$ to $7 \mathrm{ppb}$ ); $\mathrm{Pt}$ ( $<3$ to $8 \mathrm{ppb}$ ) and $\mathrm{Au}$ (1.3 to $3.9 \mathrm{ppb}$, except sample ESK 27 which has a concentration of $517.7 \mathrm{ppb}$ ) display relatively narrow variations. Cu content in the samples is relatively very low (0.69 to $11.2 \mathrm{ppm}$, except sample ESK 27 which again has a value of $50 \mathrm{ppm}$ ) while Ni contents range from 680-2622 ppm.

Table2. $\mathrm{Ni}$-Cu-Au-PGE contents of the ultramafic rocks in the Nyong Series

\begin{tabular}{|l|c|c|c|c|c|c|c|c|c|c|c|c|c|c|c|}
\hline \multicolumn{2}{|c|}{ Sample No. } & ESK 1 & ESK2 & ESK 3 & ESK 4 & ESK5 & ESK6 & ESK 7 & ESK 8 & ESK 9 & ESK 10 & ESK 11 & ESK 12 & ESK 13 & ESK 14 \\
\hline$(\mathrm{ppb})$ & d.1 & & & & & & & & & & & & & & \\
\hline $\mathrm{Pt}$ & 3 & $<3$ & $<3$ & $<3$ & $<3$ & $<3$ & $<3$ & $<3$ & $<3$ & $<3$ & $<3$ & $<3$ & $<3$ & $<3$ & $<3$ \\
\hline $\mathrm{Pd}$ & 2 & 3.00 & 3.00 & 3.00 & 4.00 & 3.00 & 3.00 & 4.00 & 3.00 & 3.00 & 3.00 & 3.00 & 4.00 & 5.00 & 5.00 \\
\hline $\mathrm{Rh}$ & 5 & $<5$ & $<5$ & $<5$ & $<5$ & $<5$ & $<5$ & $<5$ & $<5$ & $<5$ & $<5$ & $<5$ & $<5$ & $<5$ & $<5$ \\
\hline $\mathrm{Ir}$ & 1 & 4.00 & 4.00 & 7.00 & 4.00 & 4.00 & 5.00 & 4.00 & 7.00 & 2.00 & 4.00 & 2.00 & 2.00 & 2.00 & 3.00 \\
\hline $\mathrm{Os}$ & 10 & $<10$ & $<10$ & $<10$ & $<10$ & $<10$ & $<10$ & $<10$ & $<10$ & $<10$ & $<10$ & $<10$ & $<10$ & $<10$ & $<10$ \\
\hline $\mathrm{Ru}$ & 50 & $<50$ & $<50$ & $<50$ & $<50$ & $<50$ & $<50$ & $<50$ & $<50$ & $<50$ & $<50$ & $<50$ & $<50$ & $<50$ & $<50$ \\
\hline $\mathrm{Ni}(\mathrm{ppm})$ & 20 & 1461 & 1450 & 2235 & 2222 & 2133 & 2121 & 1593 & 1599 & 2489 & 2490 & 2475 & 2479 & 2615 & 2617 \\
\hline $\mathrm{Cu}(\mathrm{ppm})$ & 0.1 & 4.4 & 4.7 & 11.2 & 11 & 3.9 & 3.7 & 7.1 & 7.3 & 7.5 & 7.6 & 0.7 & 0.69 & 3.9 & 4.1 \\
\hline $\mathrm{Au}$ & 2 & 3.7 & 3.7 & 2.4 & 2.7 & 2.9 & 2.8 & 3.8 & 3 & 1.3 & 1.5 & 3.3 & 3.8 & 3.7 & 3.9 \\
\hline $\mathrm{SPGE}$ & - & 7 & 7 & 11 & 8 & 7 & 8 & 8 & 10 & 5 & 7 & 5 & 6 & 7 & 8 \\
\hline $\mathrm{AU}-\mathrm{PGE}$ & - & 10.7 & 10.7 & 13.4 & 10.7 & 9.9 & 10.8 & 11.8 & 13 & 6.3 & 8.5 & 8.3 & 9.8 & 10.7 & 11.9 \\
\hline $\mathrm{PPGE}$ & - & 7 & 7 & 11 & 8 & 7 & 8 & 8 & 10 & 5 & 7 & 5 & 6 & 7 & 8 \\
\hline $\mathrm{Pd} / \mathrm{Ir}$ & - & 0.75 & 0.75 & 0.43 & 1 & 0.75 & 0.6 & 1 & 0.43 & 1.5 & 0.75 & 1.5 & 2 & 2.5 & 1.67 \\
\hline $\mathrm{Cu} / \mathrm{Ir}$ & - & 1.1 & 1.18 & 1.6 & 2.75 & 0.98 & 0.78 & 1.78 & 1.04 & 3.75 & 1.9 & 0.35 & 0.35 & 1.95 & 1.37 \\
\hline $\mathrm{Cu} / \mathrm{Pd}$ & - & 1.467 & 1.567 & 3.733 & 2.75 & 1.3 & 1.233 & 1.775 & 2.433 & 2.5 & 2.533 & 0.233 & 0.173 & 0.74 & 0.82 \\
\hline $\mathrm{Pt}+\mathrm{Pd}+\mathrm{Au}$ & & 6.7 & 6.7 & 5.4 & 6.7 & 5.9 & 5.8 & 7.8 & 6.00 & 4.3 & 4.5 & 6.3 & 7.8 & 8.7 & 8.9 \\
\hline $\mathrm{Pt}+\mathrm{Pd}+\mathrm{Au} / \mathrm{Cu}$ & 1.52 & 1.52 & 0.57 & 0.61 & 1.15 & 1.57 & 1.11 & 0.82 & 0.57 & 0.59 & 9 & 11.3 & 2.23 & 2.17 \\
\hline $\mathrm{Pt}+\mathrm{Pd}+\mathrm{Au} / \mathrm{CaO}-$ & 134 & 134 & 270 & 670 & - & - & 390 & 200 & 4.58 & 4.89 & 42 & 48.75 & 870 & 890 \\
\hline
\end{tabular}

d.l: detection limits

Table2 (continued)

\begin{tabular}{|c|c|c|c|c|c|c|c|c|c|c|c|c|c|c|}
\hline Sample No. & & $\begin{array}{c}\text { ESK } \\
15 \\
\end{array}$ & $\begin{array}{c}\text { ESK } \\
16 \\
\end{array}$ & $\begin{array}{c}\text { ESK } \\
17 \\
\end{array}$ & \begin{tabular}{|c} 
ESK1 \\
8 \\
\end{tabular} & $\begin{array}{c}\text { ESK } \\
19 \\
\end{array}$ & $\begin{array}{c}\text { ESK } \\
20 \\
\end{array}$ & $\begin{array}{c}\text { ESK } \\
21 \\
\end{array}$ & $\begin{array}{c}\text { ESK } \\
22 \\
\end{array}$ & $\begin{array}{c}\text { ESK } \\
23 \\
\end{array}$ & $\begin{array}{c}\text { ESK } \\
24 \\
\end{array}$ & $\begin{array}{c}\text { ESK } \\
25 \\
\end{array}$ & $\begin{array}{c}\text { ESK } \\
26 \\
\end{array}$ & $\begin{array}{c}\text { ESK } \\
27 \\
\end{array}$ \\
\hline (ppb) & d.1 & & & & & & & & & & & & & \\
\hline $\mathrm{Pt}$ & 3 & $<3$ & $<3$ & $<3$ & $<3$ & $<3$ & $<3$ & $<3$ & $<3$ & $<3$ & $<3$ & $<3$ & 8 & 4 \\
\hline $\mathrm{Pd}$ & 2 & 4.00 & 3.00 & 4.00 & 4.00 & 3.00 & 4.00 & 5.00 & 4.00 & 4.00 & 4.00 & 5.00 & 5.00 & 4.00 \\
\hline $\mathrm{Rh}$ & 5 & $<5$ & $<5$ & $<5$ & $<5$ & $<5$ & $<5$ & $<5$ & $<5$ & $<5$ & $<5$ & $<5$ & $<5$ & $<5$ \\
\hline $\mathrm{Ir}$ & 1 & 4.00 & 4.00 & 4.00 & 7.00 & 4.00 & 4.00 & 3.00 & 4.00 & 4.00 & 2.00 & 2.00 & $<1$ & $<1$ \\
\hline Os & 10 & $<10$ & $<10$ & $<10$ & $<10$ & $<10$ & $<10$ & $<10$ & $<10$ & $<10$ & $<10$ & $<10$ & $<10$ & $<10$ \\
\hline $\mathrm{Ru}$ & 50 & $<50$ & $<50$ & $<50$ & $<50$ & $<50$ & $<50$ & $<50$ & $<50$ & $<50$ & $<50$ & $<50$ & $<50$ & $<50$ \\
\hline $\mathrm{Ni}(\mathrm{p}$ & 20 & 2009 & 2010 & 2188 & 2179 & 2110 & 2115 & 2619 & 2622 & 2506 & 2510 & 2456 & 2462 & 680 \\
\hline $\mathrm{Cu}(\mathrm{p}$ & 0.1 & 7.8 & 7.1 & 1.5 & 1.9 & 1 & 1.2 & 3 & 2.9 & 8.4 & 8.2 & 3.1 & 3.3 & 50 \\
\hline $\mathrm{Au}$ & 2 & 3.2 & 3.3 & 1.6 & 1.5 & 2.1 & 2.1 & 2.5 & 2.8 & 3.4 & 3.3 & 2.5 & 2.7 & 517.7 \\
\hline$\Sigma \mathrm{PGH}$ & - & 8 & 7 & 8 & 11 & 7 & 8 & 8 & 8 & 8 & 6 & 7 & 13 & 8 \\
\hline AU-PGE & - & 11.2 & 10.3 & 9.6 & 12.5 & 9.1 & 10.1 & 10.5 & 10.8 & 11.4 & 9.3 & 9.5 & 14.7 & 525.7 \\
\hline PPGE & - & 8 & 7 & 8 & 11 & 7 & 8 & 8 & 8 & 8 & 6 & 7 & 13 & 8 \\
\hline $\mathrm{Pd} / \mathrm{Ir}$ & - & 1 & 0.75 & 1 & 0.57 & 0.75 & 1 & 1.67 & 1 & 1 & 2 & 2.5 & - & - \\
\hline $\mathrm{Cu} / \mathrm{Ir}$ & - & 1.95 & 1.78 & 0.38 & 0.27 & 0.25 & 0.3 & 1 & 0.73 & 2.1 & 4.1 & 1.55 & - & - \\
\hline $\mathrm{Cu} / \mathrm{Pd}$ & - & 1.95 & 2.367 & 0.375 & 0.475 & 0.333 & 0.3 & 0.6 & 0.275 & 2.1 & 2.05 & 0.62 & 0.66 & 12.5 \\
\hline $\mathrm{Pt}+\mathrm{Pd}+\mathrm{Au}$ & - & 7.2 & 6.3 & 5.6 & 5.5 & 5.1 & 6.1 & 7.5 & 6.8 & 7.4 & 7.3 & 7.5 & 15.7 & 525.7 \\
\hline $\begin{array}{l}\mathrm{Pt}+\mathrm{Pd}+\mathrm{Au} / \mathrm{C} \\
\mathrm{u}\end{array}$ & - & 0.92 & 0.89 & 3.73 & 5.91 & 5.1 & 5.17 & 2.5 & 2.35 & 0.88 & 0.89 & 2.42 & 2.33 & 10.43 \\
\hline $\begin{array}{l}\mathrm{Pt}+\mathrm{Pd}+\mathrm{Au} / \mathrm{C} \\
\mathrm{aO}\end{array}$ & - & 56.36 & 55 & 56 & 550 & - & - & 6.58 & 6.07 & 12.13 & 12.37 & 107.14 & 85.56 & 100.91 \\
\hline
\end{tabular}

d.l: detection limits

$\mathrm{Pt}+\mathrm{Pd}+\mathrm{Au}$ values range from 4.3 to $15.7 \mathrm{ppb}$ (with the exception of sample 27 which show a value of $525.7 \mathrm{ppb}$ ) while $\mathrm{Cu} / \mathrm{Pd}$ ratios vary from 0.17 to 3.73 . Ni concentration is very high in the samples 
with a range of 680 to $2622 \mathrm{ppm}$ (Table 2). The average Pt/Pd ratio (1.4) of the ultramafic rock samples is less than that of the Merensky Reef (2.33). Also, the samples have average $\mathrm{Ni} / \mathrm{Cu}, \mathrm{Pd} / \mathrm{Ir}$ and $\mathrm{Pt} / \mathrm{Ir}$ ratios of 329.8, 1.01 and 0.06 , respectively. The Merensky Reef has average $\mathrm{Pd} / \mathrm{Ir}$ and Pt/Ir ratios of 15.4 and 3.6 , respectively while those of the Platreef are 89.5 and 75.8 respectively ( Naldrett, 1989 ). Maier et al. (2008) suggested that the difference in Pt/Pd ratios between the Merensky Reef and the Platreef is either as a result of Pd loss from the Merensky sulfides due to mobilization in late-stage magmatic or hydrothermal melts and/or fluids or enhanced partitioning of $\mathrm{Pd}$ relative to $\mathrm{Pt}$ into the sulfide melt due to the Platreef magma having a higher oxygen fugacity than the Merensky magma.

Bivariate plots of $\mathrm{Pd}$ and $\mathrm{Ir}, \mathrm{Pd}$ and $\mathrm{Pt}, \mathrm{Pt}$ and $\mathrm{Ni}, \mathrm{Cu}$ and $\mathrm{Ir}$ and $\mathrm{Cu} / \mathrm{Pd}$ show very low values of PGE in the samples than similar occurrences in other parts of the world (Figure 9a, b, c, d and e). Similarly, low Pd and Ir values have been reported by Keays (1995) in the Barbeton komattites. The low values of the PGEs in the samples indicate depleted mantle source or partial melting of the mantle where PGE were retained in the restite. Both Ir and Pt, and Ir show somewhat weak positive correlations with $\mathrm{Pd}$ and $\mathrm{Cu}$ respectively (Figure $9 \mathrm{a}, \mathrm{b}, \mathrm{d}$ ) which are similar to other comparable studies and the mafic rocks from Dabie Orogen, Central China (Qing et al. 2012)
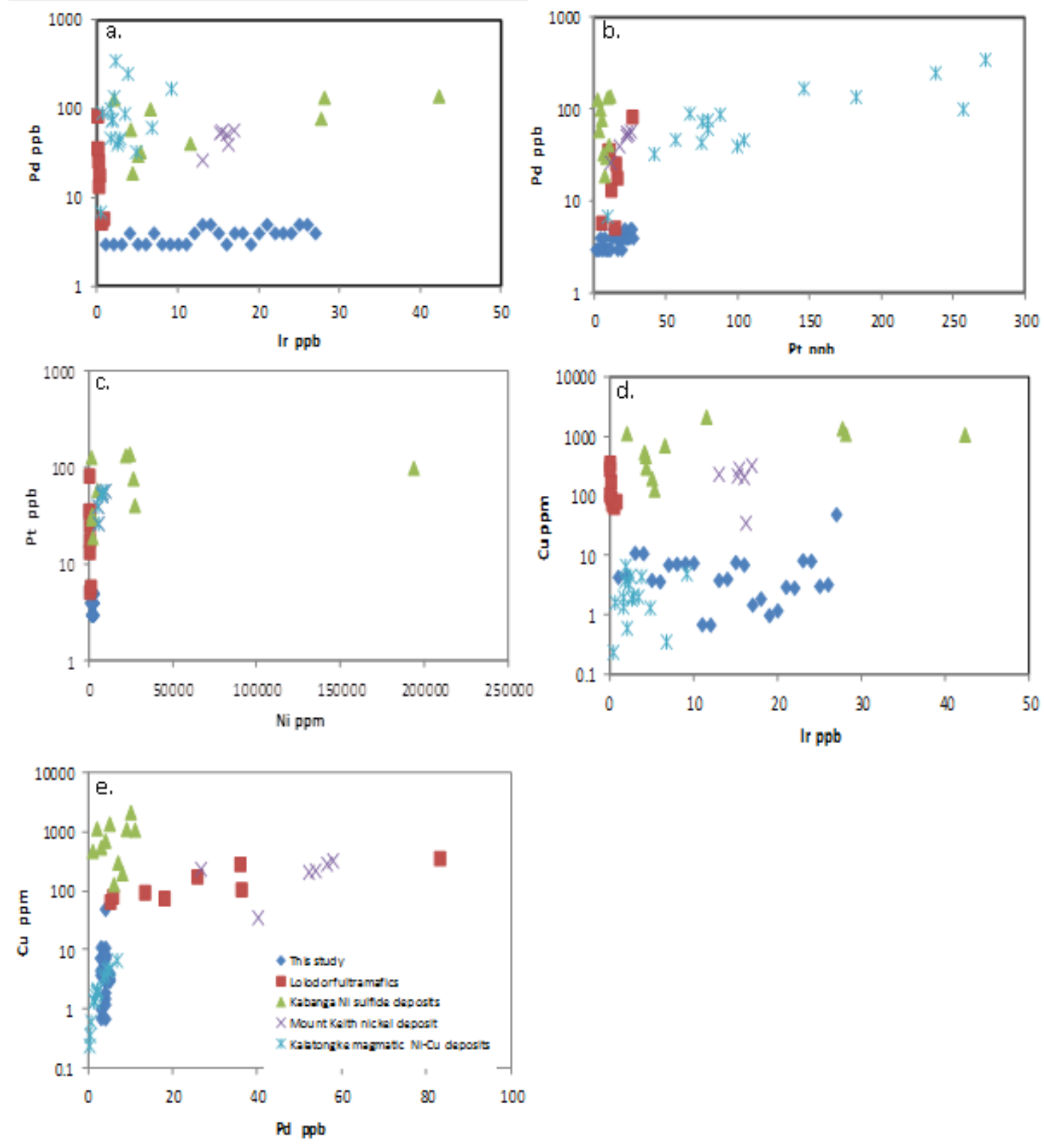

Figure9. Variation in (a) Pd/Ir, (b) Pd/Pt, (c) Pt/Ni, (d) Cu/Ir and (e) Cu/Pd contents in the ultramafic rocks of the Nyong Series with comparable studies in other parts of the world. 
Evaluation of Platinum Group Elements (PGE) Potentials of Ultramafic Rocks of the Paleoproterozoic Nyong Series, Southeast Cameroon
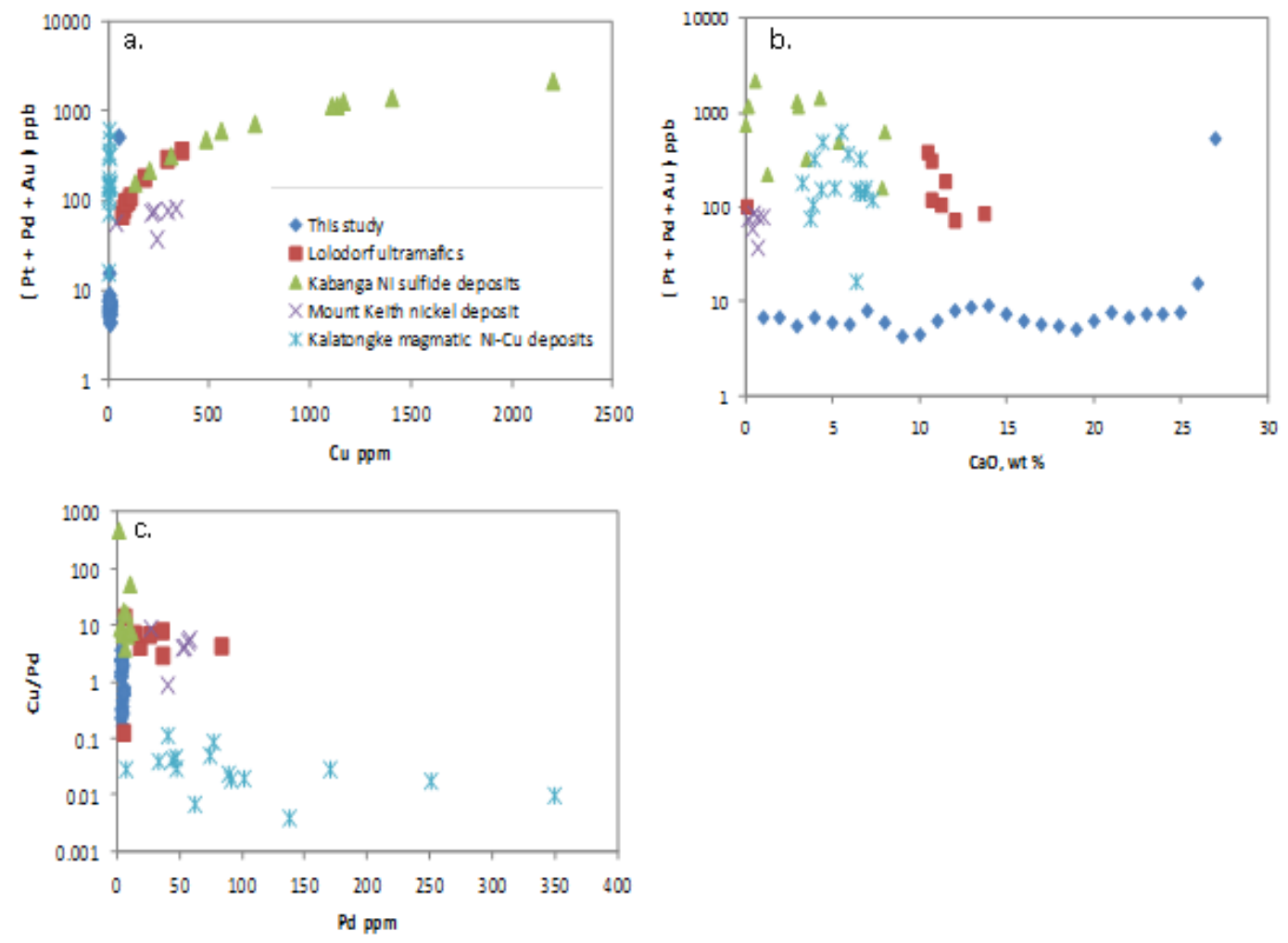

Figure10. (a) Plot of Pt $+P d+A u$ as a function of Cu contents of the samples show a general clustering of twenty-six of the twenty-seven data points with very low $\mathrm{Pt}+\mathrm{Pd}+\mathrm{Au}$ ratios for the $\mathrm{Pt}+\mathrm{Pd}+\mathrm{Au} / \mathrm{Cu} \mathrm{plot}$. (b) Plot of $\mathrm{Pt}+\mathrm{Pd}+\mathrm{Au} / \mathrm{Ca}$ a shows a progressive increase in the values of $\mathrm{CaO}$ with a narrow range value of $\mathrm{Pt}+$ $P d+A u$. (c) $C u / P d / P d$ plot displaying similar clustering of the samples as in (a) above. However, other comparable studies show more scattering of the samples.

The Au/Ir ratios (Figure 11a) has a slightly scattered relationship which is similar to the Lolodorf ultramafics but different from the Kabanga Ni sulfide deposit which has a more scattered relationship while Ni/Ir ratios (Figure 11b) has a consistent linear relationship.
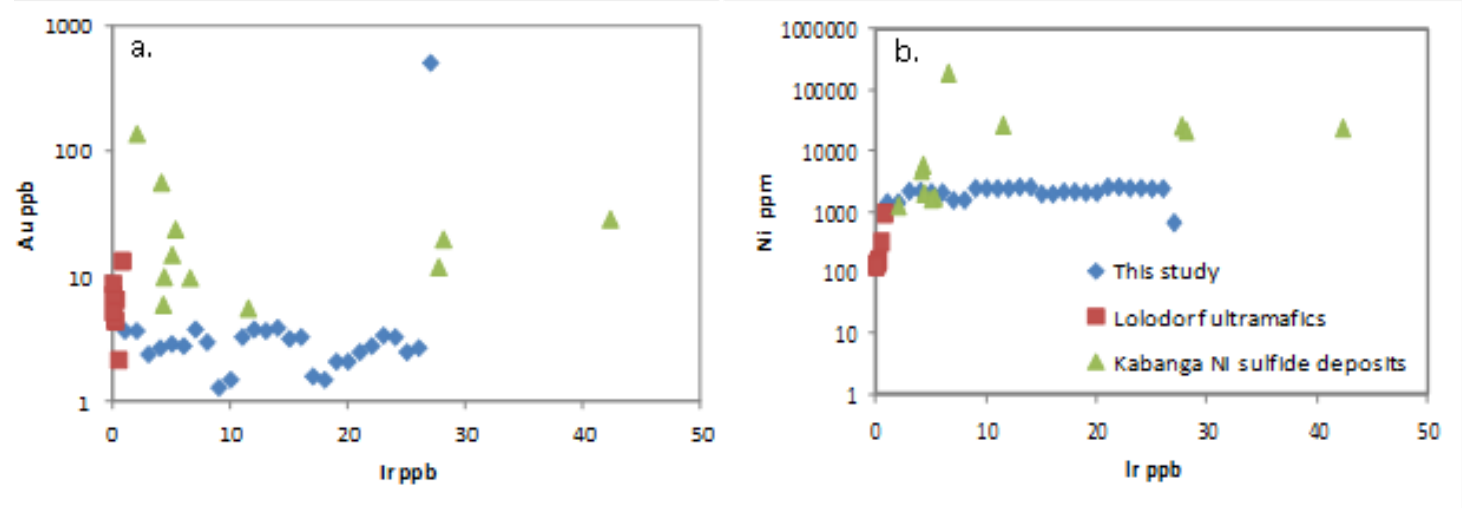

Figure11. (a) Au/Ir ratios of the ultramafic rocks from the Nyong Series showing a slightly scatter relationship which is similar to the Lolodorf ultramafics but different from the Kabanga Ni sulfide deposits which has a more scatter relationship. (b) Ni/Ir ratios show a consistent linear relationship for the ultramafic rocks while the Kabanga and the Lolodorf ultramafics show more scattered and clustered relationships respectively.

Naldrett et al. (1979) suggested that when normalized PGE values are plotted in order of descending melting point (Os, Ir, Ru, Rh, Pt, Au), a smooth curve much like REE pattern will be obtained. These PGE curves usually provide valuable information about the fertile mantle, tectonic environment of magmatism, fractionation and contamination, fluid-sulfide-silicate melt interaction during early history of magma (Barnes et al, 1985; Zhou et al., 2004; Alapieti et al, 2008; Mondal et al., 2007). Primitive mantle-normalized PGE patterns (Brügmann et al., 1987 (for Pd, Au, Ir, Ni and Cu) and Jagoutz et al., 1979 (for Pt) are presented in Figure 13a. The ultramafic rocks of the northern corner of 
the Nyong Series are characterized by abnormal PGE $+\mathrm{Au}+\mathrm{Ni}+\mathrm{Cu}$ fractionated patterns which are characterized by $\mathrm{Ni}$, Ir and $\mathrm{Au}$ occurring as peak values and depleting values of $\mathrm{Pt}, \mathrm{Pd}$ and $\mathrm{Cu}$ in some samples (Figure 12a). These patterns are similar to those of comparable rocks (Figure 12b) but the most notable characteristic of the ultramafic rocks in this study is that their PGE contents appear to be markedly lower than those of most other comparable rocks. Similarly, low Pd and Ir values were reported by Keays $(1983,1995)$ in the study of Barberton komatiites. These ultramafic rock samples are unfractionated because they do not show enrichment in either IPGE (Ir) or PPGE (Pt and Pd) (Figure 13a) unlike the comparable samples which show enrichment in both (Figure 13b). Ding et al. (2012) have reported that some massive sulfides deposit samples in the Eagle $\mathrm{Ni}-\mathrm{Cu}-\mathrm{PGE}$ deposit, Upper Michigan are unfractionated as they equally do no show enrichment in either IPGE ( Os, Ir, Ru and Rh ) or PPGE ( Pt and Pd ), which are present in other massive samples. Similar to other deposits, the samples in this study have higher normalized Ir values over Ni. Also, the Pd-Au-Cu pattern is similar.

Mondal and Zhou (2010) also reorted that the Ir-group PGE (IPGE: Ir, Os, Ru) of the sulfide-rich breccias assemblages in the Nuasahi massif were contributed from the ultramafic-chromitite breccias. Samples of the gabbro unit have fractionated primitive mantle-normalized patterns, IPGE depletion $(\mathrm{Pd} / \mathrm{Ir}=24-1,227)$ and Ni-depletion due to early removal of olivine and chromite from the primitive boninitic magma that formed the ultramafic unit.
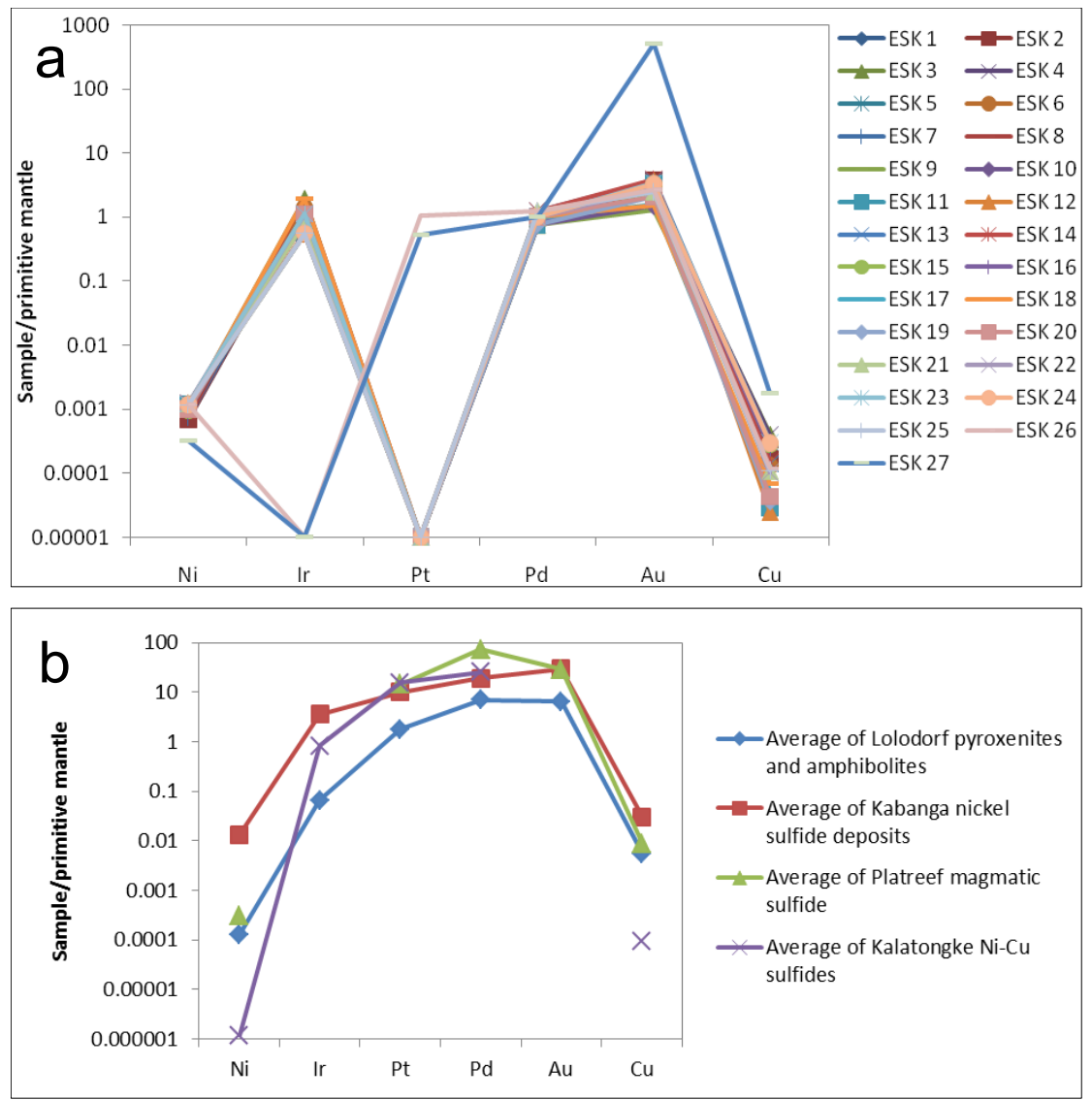

Figure13. (a) Primitive mantle-normalized PGE-Au-Ni-Cu patterns of the ultramafic rocks of the northern corner of the Nyong Series with abnormal PGE fractionated patterns which are characterized by Ni, Ir and Au occurring as peak values and depleting values of $P t, P d$ and $C u$. (b) Comparable ultramafic rock samples show enrichment in $\mathrm{Ni}, \mathrm{Ir}, \mathrm{Pt}, \mathrm{Pd}$ and $\mathrm{Au}$ and depletion in $\mathrm{Cu}$.

\section{DISCUSSION}

\subsection{Metamorphic Alteration}

The possible effect of alteration on PGEs concentration patterns in the ultramafic rocks of the Nyong Series is very obvious. All the rock samples in the study area have been pervasively altered and thus one could suggest that the relatively large amount of scatter observed for the PGEs, particularly Pt, Pd and $\mathrm{Ir}$ as well as $\mathrm{Cu}$ and $\mathrm{Au}$ (Figure $9 \mathrm{a}-\mathrm{e}$ ) could be due to remobilization of the elements during 
alteration. The available data on PGE mobility during alteration of rocks have been reviewed by Wood (2002). The data show that PGE are relatively immobile under most conditions, with Pd showing the greatest mobility. Bandyayera (1997) reported that all PGEs are immobile during lowgrade metamorphism of ultramafic rocks, but $\mathrm{Au}, \mathrm{Pd}$, and to a lesser degree, $\mathrm{Pt}$ may be remobilized during lateralization. The similarity in PGEs concentration and inter-element ratios found in all the ultramafic rock samples in the Nyong Series suggest that the PGE patterns are of a primary nature. Although there was local redistribution of the PGEs, it is unlikely that there was widespread redistribution of the PGEs. Most of PGEs (especially Os, Rh and Ru) were not detected in the studied samples (Table 2). It is suggested that these PGEs could be present either in the form of submicroscopic inclusions in sulfides and/or bound to spinel and olivine (especially $\mathrm{Ru}$ and $\mathrm{Rh}$ ) as suggested by Mondal, 2011. The ultramafic rocks of the Nyong Series are relatively altered and typically have $7.5-12.40 \mathrm{wt}$. \% loss on ignition (LOI) (Table 1), indicating varying degree of alteration. Most studies have shown that the PGE are relatively immobile during seafloor hydrothermal alteration (e.g. Crocket, 1990; Crocket, 2002), although, Barnes et al. (1985) suggested that $\mathrm{Au}$ and $\mathrm{Pt}$ are easily mobilised during alteration of talc-bearing ultramafic rocks. In the Nyong Series PGEs concentrations of the ultramafic rocks are constant, and show no significant variations between less and most altered samples or with any indicators of alteration such as LOI and therefore do not conform to this assertion.

\subsection{Sulphur Saturation and PGE Mineralization}

Cocker et al. (2014), Barnes et al. (2015) and Hughes et al. (2015) revealed that PGE geochemistry can be used to identify the onset of sulfide saturation in magmatic rocks. They hypothesized that if a fractionating magma system becomes sulfide saturated most of the PGE will be trapped in sulfides in the plutonic chamber and be unavailable to enter a magmatic hydrothermal fluid. On the other hand, if fluid saturation occurs before sulphide saturation most of the PGEs, $\mathrm{Cu}$ and $\mathrm{Au}$ will be available to partition into the hydrothermal fluid, which could lead to the formation of economic PGE deposits.

Partial melting of the primitive mantle may lead to the formation of either S-saturated or Sundersaturated melts (Chen and Xia, 2008). When the melts are S-saturated, the immiscible sulfide liquids will separate from the primary melt as the temperature and pressure decrease, and be retained in the residual mantle, resulting in a PGE-poor melt because of the siderophile nature of PGE. When S-undersaturated magma is formed by high degree of partial melting, the PGE remain in the primary melt, leading to PGE, especially PPGE enrichment (Smith et al., 2014). S-undersaturation would require at least $25 \%$ partial melting of the mantle source (Keays, 1995).

Lesher and Barnes (2009) and Naldrett et al. (2009) suggest that timing of sulphur saturation condition is very important to the crystallisation of PGMs in ultramafic rocks. Crystallisation of PGM progresses with different types of mineral paragenesis depending upon the prevailing sulphur saturation conditions in time and space (Naldrett, 2010 and Dare et al., 2014). For instance, if sulphur saturation coincides with magnetite and chromite crystallization, IPGE will concentrate in the chromite and Pyrrhotite minerals. On the other hand, if sulphur saturation does not coincide with chromite crystallisation, then $\mathrm{Os}$, Ir and Ru may be concentrated in chromite matrix and $\mathrm{Pt}, \mathrm{Pd}$, and $\mathrm{Rh}$ will be absent, and later PPGE minerals may occur in disseminated forms with Ni. If sulphur saturation occurs in the absence of or for prolonged period after chromite crystallsation, PGE will associate with base metal sulphides. However, if sulphur saturation prevailed much before the chromite crystallization, PGE will be crystallised at greater depth and chromite will have very poor values of PGE (Barnes 1990; Maier, 2005). Retention of FeO phases, i.e., chromite, fayalite and magnetite, perhaps, inhibited sulphur saturation in the system and retarded PGE and sulphide crystallisation in the ultramafic rocks of the Nyong Series. Once the magma has been emplaced into the crust it must become saturated in a base metal sulfide liquid (dominantly FeS) in order for it to have the potential to form a Ni sulfide deposit. It is this sulfide liquid that collects the metals (Barnes and Lightfoot, 2005; Holwell and McDonald, 2010).

Sulphide segregation during ascent/or emplacement may thus be advanced for the relatively low PGE concentrations in ultramafic rocks in the Nyong Series. There are many examples of mafic-utramafic rocks depleted in PGE relative to $\mathrm{Cu}$ and $\mathrm{Ni}$ (e.g. Duluth, Theriault et al., 2000; Pechenga, Barnes et al., 2001; Maier et al., 2003; Sababa et al., 2015). Such cases seem to be the result of sulphide 
segregation in the crust. Good examples of mafic-ultramafic rocks with similarly low PGE contents to the present samples are the Voisey's Bay Intrusion (VBI) located in the Mesoproterozoic Nain Plutonic Suite (NPS) in Labrador, Canada (Lightfoot et al., 2012; Lightfoot and Keays, 2005), Kalatonke magmatic Ni-Cu deposits in the Central Orogenic Belt, NW China (Li et al., 2012) and Mt. Keith Komatiites in Australia (Dowling and Hill, 1992) where sulphide segregation in the crust is the suspected and preferred model. The PGE depletion is important because this provides a strong indication that rocks that are genetically linked to the $\mathrm{Ni}$ sulfide ores record evidence of metal depletion due to sulfide formation. A small amount of crystallization of olivine or sulfides will not lower the $\mathrm{Ni}$ content of the magma appreciably, and a viable Ni deposit may form from this magma (Barnes and Lightfoot, 2005). However, removal of sulfides will sharply deplete the magma in PGE and mildly deplete it in $\mathrm{Cu}$ (Figure $9 \mathrm{a}$ - e and 4.20). Any sulfide liquid that forms subsequently will be depleted in PGE relative to $\mathrm{Ni}$ and $\mathrm{Cu}$. Prior removal of sulfides may be one of the main reasons why some Ni sulfide deposits have low PGE contents compared to others. This may be the case of the Nyong Series because the rocks are Ni-rich but PGE-depleted (Table 2 and Figure 9a). Smith et al. (2014) suggested an alternative mechanism of depleting magma of PGE. They proposed that mixing of residual and primitive magmas can induce $S$ saturation, consequently depleting the magma of its metals. In this model, the sequence still segregates at depths and the resulting ultramafic rocks are PGE-poor. It is therefore suggested that the amount of sulfide melt that formed the Nyong Series rocks was enough to strip the PGE from the magma, which explain why this rocks are PGE-depleted. PGEs are strongly siderophile elements, which provide valuable information on the petrogenesis of mantle-derived igneous rocks (Randive et al., 2015; Gwalani et al., 2015). Os, $\mathrm{Ru}$ and $\mathrm{Rh}$ are completely absent in the rocks of the study area and Pt, Pd and Ir do not seem to be present in significant concentrations. Therefore, it is argued here that the Nyong Series rocks are not completely "barren" of PGE minerals.

Removal of a small percentage of sulphide and accumulation of olivine could account for the distribution of $\mathrm{Cu}$ and $\mathrm{Pd}$ in the ultramafic rocks in the Nyong Series (Figure 9e) but is unlikely proposition in view of the uniform PGE depletion observed in these rocks (Table 4. 5)

\subsection{Economic Potential of Finding PGE in the Rocks/Implication to Exploration}

The ultramafic rocks in the Nyong Series have very low PGE contents. Os, Rh and Ru are completely absent in the samples. These low PGE data suggest that the potential of these ultramafic rocks to produce exploitable PGE deposits is very low. However, there is also the possibility that the Nyong Series ultramafic intrusions are feeder intrusions with the implication that further PGE-rich sulphides were transported into wherever these feeder intrusions deposited them, either as lavas or possibly large-scale gabbro intrusions (e.g. Holwell et al., 2012). On the other hand as stipulated above that the Nyong ultramafic intrusions are feeder intrusions, there may be further PGE deposits at depth and the mineralization in the studied ultramafic rock intrusions may simply represent a small fraction of a much large volume of sulphides. This will be related to having a larger body of magma at depth in which both PGE enrichment and sulphide saturation occurred. Huminicki et al., 2008 and Kozlu et al., 2014, have reported similar situations in which sulphide droplets in intrusion systems such as sills and dykes describe this style of mineralization above areas of PGE mineralization and sulphide saturation.

\section{CONClusion}

Ultramafics in the Nyong Series are altered and metamorphosed resulting in low PGE concentration and despite their high $\mathrm{MgO}$ and $\mathrm{Ni}$ contents, low PGE contents suggest that the magma is derived from PGE-poor/depleted mantle. Low Cu-Au-PGE content in the rocks suggests melt produced in an oceanic ridge setting capable of forming major Ni sulphide deposits. Finally, this points to the fact that PGE occurrences could be identified at greater depth. The results of this study are very relevant to further exploration and research work in the area.

It is however, not clear what the chemical composition of the layer beneath the studied samples is as ssuch data may be very useful in judging the PGE potential in the region.

Similarly, it is also recommended that whenever drill cores or fresh samples become available in this area, whole rock geochemical studies of the rocks should be determined in order to further ascertain the PGE potential of the area. 


\section{ACKNOWLEDGEMENT}

This article is part of the PhD thesis of the first author supervised by Prof. C. E. Suh (CES) at the University of Buea, Cameroon and completed within the research framework of economic geology on the Precambrian Mineral belt of Cameroon supported by University of Buea, Faculty Grants to CES. We gratefully acknowledge funding from the AvH Stiftung, Germany (courtesy of CES) and the Research grant in support of this thesis from the national body of Academic Staff Union of Universities (ASUU, Nigeria).

\section{REFERENCES}

[1] Ako, T. A., Vishiti, A., Ateh, K. I., Kedia, A. C. and Suh, C. E. (2015). Mineral Alteration and Chlorite Geothermometry in Platinum Group Element (PGE)-bearing meta-ultramafic rocks from South East Cameroon. Journal of Geosciences and Geomatics, 3 (4): 96-108

[2] Alapieti, T. T., Devaraju, T. C. and Kaukonen, R. J. (2008). PGE mineralization in the late Archaean ironrich mafic-ultramafic Hanumalapur Complex, Karnataka, India. Contributions to Mineralogy and Petrology, 92: 99-128.

[3] Balaram, V., Singh, S. P., Satyanarayanan, M. and Anjaiah, K. V. (2013). Platinum group elements geochemistry of ultramafic and associated rocks from Pindar in Madarawa Igneous Complex, Bundlkhand massif, Central India. Journal of Earth System Sciences, 122 (1): 79-91.

[4] Ballhaus, C and Ryan, C, G. (1995). Platinum-group elements in the Merenskey Reef. 1. PGE in base metal sulfides and the down-temperature equilibrium history of Merensky ores. Contributions to Mineralogy and Petrology, 122 (3): 241-251.

[5] Bandyayera, D. (1997). Formation des laterites nickelifère et mode de distribution des elements du groupe du platine dans les profils lateritiques du complexe de Musongati, Burundi. PhD Thesis, Université du Québec à Chicoutimi (440).

[6] Barnes, S. J., Fiorentini, M. L. and Fardon, M. C. (2012). Platinum group element and nickel sulphide ore tenors of the Mount Keith nickel deposit, Yilgarn Craton, Australia. Mineralium Deposita, 47: 129-150.

[7] Barnes, S-J. 1990. The use of metal ratios in prospecting for a platinum-group element deposit. Journal of Geochemical Exploration, 37 (1): 91-99.

[8] Barnes, S-J. and Lightfoot, P.C. (2005). Formation of magmatic nickel-sulfide ore deposits and processses affecting their copper and platinum-group element contents. In Hedenquist, J. W., Thompson, J.F.H., Goldfarb, R.J. and Richards, J.P. (eds.) Economic Geology $100^{\text {th }}$ Anniversary Volume, 179-213.

[9] Barnes, S-J., Cox, R. A. and Zientek, M. L. (2006). Platinum-group element, gold, silver and base metal distribution in compositionally zoned sulfide droplets from the Medvezky Creek mine, Noril'sk, Russia. Contributions to Mineralogy and Petrology, 152: 187-200.

[10] Barnes, S-J., Melehik, V. and Sokolov, S. V. (2001). The composition and mode of formation of the Pechenga nickel deposits, Kola peninsula, north-western Russia. Canadian Mineralogist, 39: 447-472.

[11] Barnes, S-J., Naldrett, A. J., and Gorton, M. P. (1985). The origin of the fractionation of platinum-group elements in terrestrial magmas. Chemical Geology, 53: 303-323.

[12] Barnes, S-J., Pagé, P., Prichand, H. M., Zientek, M. I. and Fisher, P. C. (2015). Chalcophile and platinumgroup element distribution in the Ultramafic series of the Stillwater Complex, MT, USA - Implications for processes enriching chromite layers in Os, Ir, Ru and Rh. Mineralium Deposita, (doi:10.1007/s00126-0150587-y) Retrived online on 10/08/15.

[13] Bonhomme, M. G., Gauthier-Lafaye, F. and Weber, F. (1982). An example of Lower Proteroizoic sediments: the Francevillian in Garbon. Precambrian Research, 18: 87-102.

[14] Bourdelle, F., Parra, T., Chopin, C. and Beyssac, O. (2013). A new chlorite geothermometer for diagnostic low-grade metamorphic conditions. Contributions to Mineralogy and Petrology, 165: 723-735.

[15] Brügmann, G. E., Arndt, N. T., Hofmann, A. W. and Tobschall, H. J. (1987). Noble metal abundances in komatiite suites from Alexo, Ontario, and Gorgona Island, Colombia. Geochimica et Cosmochimica Acta, 51: $2159-2170$.

[16] Campos-Alvarez, N. O., Lain, M. S. and Brain J. F. (2012). The roles of magmatic and hydrothermal processes in PGE mineralization, Ferguson Lake Deposit, Nunavut, Canada. Mineralium Deposita, 47: 441-465.

[17] Chen, G. and Xia, B. (2008). Platinum-group elemental geochemistry of mafic and ultramafic rocks from the Xigaze ophiolite, Southern Tibet. Journal of Asian Earth Sciences, 32: 406-422.

[18] Cocker, H. A., Park, J. W., Campbell, I. H. and Valente, D. L. (2014). Why El Abra is Cu-only porphyry. Goldschidt Abstracts, 438 
Evaluation of Platinum Group Elements (PGE) Potentials of Ultramafic Rocks of the Paleoproterozoic Nyong Series, Southeast Cameroon

[19] Cox, K. G., Bell, J. D. and Pankhurst, R. J. (1979). The interpretation of igneous rocks. London, George Allen \& Unwin (450).

[20] Crocket, J. H. (1990). Noble metals in seafloor hydrothermal mineralizations from Juan de Fuca and MidAtlantic ridge: a fractionation of gold from platinum metals in hydrothermal fluids. Canadian Mineralogist, 28: 639-648.

[21] Crocket, J. H. (2002). Platinum-group elements in basalts from Maui, Hawai'i: low abundances in alkali basalts: Canadian Mineralogist, 40: 585-610

[22] Crocket, J. H. and Paul, D. K. (2004). Platinum-group elements in Deccan mafic rocks: a comparison of suites differentiate by Ir content. Chemical Geology, 208: 273 - 291.

[23] Dare, S. A. A., Barnes, S. J. and Prichard, H. M. (2010). The distribution of platinum group elements (PGE) and chalcophile elements among sulfides from the Creighton Ni-Cu-PGE sulfide deposit, Sudbury, Canada, and the origin of palladium in pentlandite. Mineraluim Deposita, 45 (8): 765-793.

[24] Dare, S. A. A., Barnes, S-J., Prichard, H., and Fisher, P. C. (2014). Mineralogy and geochemistry of Curich ores from the McCreedy East Ni-Cu-PGE Deposit (Sudbury, Canada): Implications for the behavior of platinum group and chalcophile elements at the end of crystallization of a sulfide liquid. Economic Geology, 109 (2): 343-366.

[25] De La Roche, H., Leterrier, J., Grandclaude, P. and Marchal, M. (1980). A classification of volcanic and plutonic rocks using R1 R2 - diagram and major element analyses - its relationships with current nomenclature. Chemical Geology, 29: 183-210.

[26] Ding, X., Ripley, E. M. and Li, C. (2012). PGE geochemistry of the Eagle Ni-Cu-(PGE) deposit, Upper Michigan: constraints on ore genesis in a dynamic magma conduit. Mineralium Deposita, 47: 89-104.

[27] Dowling, S. E. and Hill, R. R. T. (1992). The distribution of PGE in fractionated Archaean Komatiites, Western and Central ultramafic units, Mount Keith Region, Western Australia. Australian Journal of Earth Sciences, 39: 349-363.

[28] Ebah Abeng, A. S., Ndjigui, P-D., Beyanu, A. A., Tessontsap, T. and Bilong, P. (2012). Geochemistry of pyroxenites, amphibolites and their weathered products in the Nyong unit, SW Cameroon (NW border of Congo Craton): Implications for Au-PGE exploration. Journal of Geochemical Exploration, 114: 1 - 19.

[29] Feybesse, J. L., Barbosa, J., Ledru, P., Guerrot, C., Jahan, V, Trboulet, V., Bouchot, V., Prian, J. P. and Sabaté, P. (1998). Paleoproterozoic tectonic regime and makers of the Archaean/proterozoic boundary in the Congo-São Francisco craton. EUG 8, Terra abstracts, 100.

[30] Feybesse, J. L., Johan, V., Maurizot, P. and Abessol, A. (1986). Evolution tectono-métamorphique libérenne et éburnéenne á la partie NW du craton zaïrọis (SW Cameroon). Current Research In Africa Journal of Earth Sciences, Matheis and Schandelmeier (eds) Balkema, Rotterdam: 9 - 12.

[31] Godel, B., Barnes, S. J. and Maier, W. D. (2007). Platinum-Group-Elements in Sulphide Minerals, Platinum- Group Minerals, and whole-rocks of the Merensky Reef (Bushveld Complex, South Africa): Implications for the formation of the Reef. Journal of Petrology, 48(8): 1569-1604.

[32] Gwalani, L. G., Rogers, K., Stoppa, F., Downes, P. J., Randive, K., Hari, K. R. and Bucha, M. (2015). Special Issue (part 11): Mafic-ultramafic rocks and alkaline-carbonatic magmatism and associated hydrothermal mineralization - dedicated to Lia N. Nokogarko, Open Geosciences, 7: 193- 196.

[33] Holwell, D. A. and McDonald, I. (2010). A review of the behavior of platinum group elements within natural magmatic sulfide ore systems. Platinum Metals Review, 54(1): 26-36.

[34] Holwell, D. A., Abraham-James, T., Keays, R. R. and Boyce, A. J. (2012). The nature and genesis of marginal Cu-PGE-Au sulphide mineralization in Paleogene Macrodykes of the Kangerlussuaq region, East Greenland. Mineralium Deposita, 47: 3-21.

[35] Hughes, H. S. R., McDonald, A. and Kerr, A. C. (2015). Platinum-group element signatures in the North Atlantic Igneous Province; Implications for mantle controls on metal budgets during continental break up. Lithos. http://dx.doi.org/10.1016/j.Lithos.2015.05.005.

[36] Huminiki, M. A. E., Sylvester, P. J. Lastra, R, Cabri, L. J., Evans-Lamswood, D. and Wilton, D. H. C. ( 2008). First report of platinum-group minerals from a hornblende gabbro dyke in the vicinity of Southeast Extension Zone of the Voisey's Bay Ni-Cu-Co deposit, Labrador. Contribution to Mineralogy and Petrology, 92: 129-164.

[37] Hutchinson, D. and McDonald, I. (2008). Lasser ablation ICP-MS study of platinum-group elements in sulphides from Platreef at Turfpruit, northen limb of the Bushveld Complex, South Africa. Mineralium Deposita, 43(6): 695-771. 
[38] Ihlenfeld, C. and Keays, R. R. (2011). Crustal contamination and PGE mineralization in the Platreef, Bushveld Complex, South Africa: evidence for multiple contamination events and transport of magmatic sulfides. Mineraliun Deposita, 46: 813-832

[39] Irvine, T. A. and Baragar, W. R. A. (1975). A guide to the chemical classification of the common volcanic rocks. Canadain Journal of Earth Sciences, 8: 523-546.

[40] Jagoutz, E., Palme, H., Baddenhausen, H., Blum, K., Cendales, M., Breibus, G., Spettel, B., Lorenz, V. and Wänke, H. (1979). The abundances of major, minor and trace elements in the earth's mantle as derived from primitive ultramafic nodules. Proceedings of the $10^{\text {th }}$ Lunar Science Conference. Geochimica et Cosmochimica Acta Supplement, 2031-2050.

[41] Jordt-Evangelista, H. (1996). Igneous charnockites in the southeastern transition zone between the São Francisco Craton and the Costeiro Mobile Belt, Brazil. Revista Brasileira de Geosciências, 26: 93-102.

[42] Keays, R. R. and Lightfoot, P. C. (2010). Crustal sulfur is required to form magmatic Ni-Cu sulfide deposits: Evidence from chalcophile element signatures of Siberian and Deccan Trap basalts. Mineralium Deposita, 45: 241-257.

[43] Keays, R. R. (1983). Archean gold deposits and their source rocks: the upper mantle connection. In: Foster, R. P. (ed.) Gold '82-the Geology, Geochemistry and Genesis of Gold Deposits. Rotterdam: Balkema, 17-51.

[44] Keays, R. R. (1995). The role of komatiite and picritic magmatism and S-saturation in the formation of ore deposits, Lithos, 34: 1-18..

[45] Kozlu, H., Prichard, H. M., Melcher, F., Fisher, P.C., Brough, C. P. and Stueben, D. (2014). Platinum group element (PGE) mineralisation and chromite geochemistry in the Berit ophiolite (Elbistan/Kahramanmaraş), SE Turkey. Ore Geology Reviews, 60: 97-111.

[46] Lasserre, M. and Soba, D. (1976). Age libérien de granodiorites et des gneiss à pyroxene du Cameroon méridional. Bullutin, B.R.G.M. 2è série, section IV (I): 17 - 32.

[47] Lerouge, C., Cocherie, A., Toteu, S. F., Penaye, J., Mile'si. J., Tchameni. R., Nsifa, E. N. Fanning, C. M. and Deloule, E. (2006). Shrimp U-Pb Zircon age for Paleoproterozoic sedimentation and 2.05Ga syntectonic plutonism in the Nyong Group, South-Western Cameroon: consequences for the Eburnean Transamazonian belt of NE Brazil and Central Africa. Journal of African Earth Sciences, 44(4/5): 413427.

[48] Lesher, C. M. and Barnes, S-J. (2009). Komatiite-associated Ni-Cu-(PGE) Deposits; In: Magmatic NiCuPGE deposits: Genetic models and exploration, edited by Li, C. and Ripley, E. M. Geological Publishing House of China, Beijing, 27-101.

[49] Li, C., Zhang, M., Fu, P., Qian, Z., Hu, P. and Ripley, E. M. (2012). The Katatongke magmatic Ni-Cu deposits in the Central Asian Orogenic Belt, NW China: product of slab window magmatism? Mineralium Deposita. 47: 51-67.

[50] Lightfoot, P. C. and Keays, R. R. (2005). Siderophile and chalcophile metal variations in flood basalts from the Siberian trap, Noril'sk region: Implication for the origin of the Ni-Cu-PGE sulfide ores. Economic Geology, 100: 439-462.

[51] Lightfoot, P. C., Keays, R. R., Evans-Lambswood, D. and Wheeler, R. (2012). S-saturation history of Nain Plutonic Suite mafic intrusions: origin of the Voisey's Bay deposit, Labrador, Canada. Mineralium Deposita, 47: 23-50.

[52] Maier, W. D. (2005). Platinum-group element deposits and occurrences: Mineralisation styles, genetic concepts and exploration criteria. Journal African Earth Sciences, 41: 165-191.

[53] Maier, W. D., Barnes, S-J., Chinyepi, G., Barton Jr, J. M., Eglington, B. and Setshedi, I. (2008). The composition of magmatic Ni-Cu-(PGE) sulfide deposits in the Tati and Selebi-Phikwe belts of eastern Botswana. Mineralium Deposita, 43: 37-60.

[54] Maier, W. D., Barnes, S-J., Sarkar, A., Ripley, E., Li, C. and Livesey, T. (2010). The Kabanga Ni Sulfide deposit, Tanzania: 1. Geology, petrography, silicate rock geochemistry, and sulfur and oxygen isotopes. Mineralium Deposita, 45: 419 - 441.

[55] Maier, W. D., Howard, H. M., Smithies, R. H., Yang, S. H., Barnes, S-J., O’Brien, H. and Gardoff, S. (2015). Magmatic ore deposits in mafic-ultramafic intrusions of Giles Event, Western Australia. Ore Geology Reviews, 71: 405 - 436.

[56] Maier, W. D., Barnes, S-J. and Groves, D. (2013). The Bushveld Complex, South Africa: formation of platinum-palladium, chrome-and vanadium rich layers via hydrodynamic sorting of a mobilized cumulate slurry in a large, relatively slowly cooling subsiding magma chamber, Mineralium Deposita, 48: 1-56 
[57] Maier, W. D., Roelofse, F. and Barnes, S-J. (2003). The Concentration of the Platinum-Group Elements in South African Komatiites: Implications for Mantle Sources, Melting Regime and PGE Fractionation during Crystallization. Journal of Petrology, 44 (10): 1787-1804.

[58] Maurizot, P., Abessolo, A., Feybesse, A., Johan, V. and Lecomte, P. (1986). Etude et prospection minière du sud-Ouest Cameroon. Sythèse des travaux de 1978 á 1995. 85-CMR 066 BRGM.

[59] Middlemost, E. A. K. (1985). Naming materials in the magma/igneous rock system. Earth Sciences Reviews, 37: 225-224.

[60] Momme, P., Oskarsson, N. and Keays, R. R. (2003). Platinum-group elements in the Icelandic rift system: melting processes and mantle sources beneath Iceland. Chemical Geology, 196: 209 - 234

[61] Momme, P., Tegner, C., Brooks, C. K. and Keays, R. R. (2002). The behavior of platinum-group elements in basalts from the East Greenland rifted margin. Contribution to Mineralogy and Petrology, 143: 133 153.

[62] Mondal, S. K. (2011). Platinum Group Elements (PGE) Geochemistry to understand the Chemical Evolution of the Earth's Mantle. Journal of Geological Society of India, 77: 295 - 302.

[63] Mondal, S. K. and Frei, R. and Ripley, E. M. (2007). Os isotope systematic of Archaean Chromite PGE deposits in the Singhbhum Craton (India): Inplication for the evolution of lithospheric mantle. Chemical Geology, 244: 391-408

[64] Mondal, S. K. and Zhou, M. F. (2010). Enrichment of PGE through interaction of evolved boninitic magmas with early formed cumulates in a gabbro-breccia zone in the Mesarchaean Nuasahi massif (eastern India). Mineralium Deposita, 45(1), 69-91.

[65] Naldrett, A. J. (1989). Magmatic sulfide deposits. Oxford University Press Monographs on Geology and Geophysics, 14 (186).

[66] Naldrett, A. J. (1997). Key factors in the genesis of Noril'sk, Sudbury, Jinchuan, Voisey's Bay and other world-class Ni-Cu-PGE deposits: Implications for exploration: Australian Journal of Earth Sciences, 44(3): 283-315.

[67] Naldrett, A. J. (2004). Magmatic sulfide deposits: Geology, Geochemistry and Exploration SpringerVerlag, Berlin and Heidelberg, Germany (727).

[68] Naldrett, A. J. (2010). Secular Variation of Magmatic Sulfide Deposits and their Source Magmas. Economic Geology, 105: 669 - 688.

[69] Naldrett, A. J., Wilson, A., Kinnaird, J and Ghunnet, G. (2009). PGE tenor and metal ratios within and below the Merensky Reef, Bushveld Complex, South Africa: Implication for its genesis. Journal of Petrology, 50: 625-659.

[70] Ndema Mbongue, J. L., Ngnotue, T., Ngo Nlend, C. D., Nzenti, J. P. and Cheo Suh, E. (2015). Origin and Evolution of the Formation of the Cameroon Nyong Series in the Western Border of the Congo Craton. Journal of Geosciences and Geomatics, 2(2): 62- 75.

[71] Owona, S. (2008). Archaean, Eburnean and Pan-African Features and Relationships in their Junction Zone in the South of Yaounde (Cameroon). PhD Thesis, University of Douala, (232).

[72] Owona, S., Mvondo, J. O., Ekodeck, G. E. (2013). Evidence of quartz, feldspar and amphibole crystal plastic deformation in the Paleoproterozoic Nyong complex shear zones under amphibolites to granulite conditions (West Central African Fold Belt, SW Cameroon). Journal of Geography and Geology, 5(3): 186-201.

[73] Owona, S., Schulz, B., Ratschbacher, L., Ondoa, J. M., Ekodeck, G. E., Tchoua, F. M. and Affaton, P. (2011). Pan-African Metamorphism evolution in the southern Yoaunde Group (Qubannguide Complex, Cameroon) as revealed by EMP-Monazite dating and thermobarometry of garnet metapelites. Journal of African Earth Sciences, 59: 125-139.

[74] Pearce, T. H., Gorman, B. E. and Birkett, T. C. (1977). The relationship between major element geochemistry and tectonic environment of basic and intermediate volcanic rocks. Earth and Planetary Science Letters, 36: 121-132.

[75] Pénaye, J., Toteu, S. F., Tchameni, R., Van Schmus, W. R., Tchakounté, J., Ganwa, A., Minyem, D. and Nsifa, E. N. (2004). The 2.1 Ga West Central African Belt in Cameroon: extension and evolution. Journal of African Earth Sciences, 39: 159-164.

[76] Power, M. R., Pirrie, D., Jedwab, J. and Stanley, C. J. (2004). Platinum-group element mineralization in an As-rich magmatic sulfide system, Talnotry, southwest Scotland: Mineralogical Magazine, 68: 395-411.

[77] Qi, L. and Zhou, M. F.(2008). Platinum-group elemental and Sr-Nd-Os isotopic geochemistry of Permain Emeishan flood basalts in Guizhou Province, SW China. Chemical Geology, 248: 83 - 103. 
[78] Qing, L. Quanlin, H. Liewen, X. Hui, L. Shanqin, N. and Yudong, W. (2012). Different Origins of the Fractionation of Platinum-Group Elements in Raobazhai and Bixi Ling Mafic Rocks from Dabie Orogen, Central China. Journal of Geological Research, (2012): 1-11.

[79] Randine, K., Kumar, J. V. and Korakoppa, M. (2015). Platinum-group elements mineralization in the cumulate gabrro of Phenai Mata Complex, Deccan Large Igneous Province, India. Current Science, 108 (10): $1796-1798$.

[80] Sababa, E., Ndjigui, P-D, Ebah Abeng, A. S. and Bilong, P. (2015). Geochemistry of peridotite xenoliths from Kumba and Nyos areas (Southern part of the Cameroon Volcanic Line): Implication for Au-PGE exploration. Journal of Geochemical Exploration. http;//dx.doi.org/10.1016/j.gexplo.2015.02.003.

[81] Savard, D., Barnes, S. J. and Meisel, T. (2010). Comparison between Nickel-Sulfur Fire Assay Te CoPrecipitation and isotope Dilution with High-Pressure Asher acid digestion for the determination of platinum-group elements, rhenium and gold. Geo-Standards and Geoanalytical Research, 34 (34): 281291.

[82] Smith, J. W., Holwell, D. A. and McDonald, I. (2014). Precious and base metal geochemistry and mineralogy of Grasvally norite-pyroxenite-anorthosite (GNPA) member, northern Bushveld Complex, South Africa: Implications for multistage emplacement. Mineralium Deposita, 49: 667- 692.

[83] Song, X. Y., Keays, R. R., Zhou, M. F., Qi, L., IhIenfeld, C. and Xiao, J. F. (2009a) Siderophile and chalcophile elemental constraints on the origin of the Jinchuan $\mathrm{Ni}-\mathrm{Cu}-(\mathrm{PGE})$ sulfide deposit, NW China. Geochimica et Cosmochimica Acta, 73: 404-424

[84] Song, X. Y., Keays, R. R., Xiao, L., Qi, H. W. and Ihlenfeld, C, (2009b). Platinum-group element geochemistry of the continental flood basalts in the central Emeishan Large Igneous Province, SW China. Chemical Geology, 262: 246 - 261

[85] Tack, L., Wingate, M. T. D., Liégeois, J. P., Fernadez- Alonso, M. and Deblond, A. (2001). Early Neoproterozoic magmatism (1000-910Ma) of the Zadinian and Ma-yumbian Groups (Bas-Congo): Onset of Rodinia rifting at the western edge of the Congo Craton. Precambrian Research, 110: 277-306.

[86] Thériault, R. D. Barnes, S-J., and Severson, M. J. (2000). Origin of Cu-Ni-PGE sulfide mineralization in the Partridge River intrusion, Duluth Complex, Minnesota: Economic Geology, 95: 929-944.

[87] Thomas, R. J., Chevallier, L. P., Gresse, P., Harmer, R. E., Eglington, B. M., Armstrong, R. A., DeBeer, C. H., Martini, J. E. J., de Kock, G. S., Macey, P. H. and Ingraham, B.A.(2002). Precambrian evolution of the Sirwa Window, Anti-Atlas Orogen, Morocco. Precambrian Research: 118, 1-57.

[88] Toteu, F. S., Van Schmus, W. R., Penaye, J. and Nyobé, J. B. (1994b).U-Pb and Sm-Nd evidence for Eburnean and Pan-African high grade metamorphism in cratonic rocks of Southern Cameroon. Precambrian Research, 67: 321-347.

[89] Toteu, S. F., Pénaye, J., Van Schmus, W. R. and Michard, A. (1994a). Preliminary U-PB and Sm-Nd geochronologic data on the North Central Cameroon: Contribution of the Archaean and Paleoproterozoic crust to the edification of an active domain of the Pan-African orogeny. Canadian Research of Acadamic Sciences, Paris, 319(Series II): 1519 - 1524.

[90] Vicat, J. P., Ngounouno, I. and Pouclet, A. (2001). Existence de dyke doléritiques anciens à composition de tholéiites continentale au sein de la province alcaline de la ligne du Cameroun. Implication sur le contexte géodynamique. Comptes Rendus de l'Académie des Sciences, Paris, 332: 243-249.

[91] Wood, S. A. (2002). The aqueous chemistry of the platinum-group elements with application in ore deposits. In: Mineralogy and Mineral Beneficiation of Platinum-Group Elements. Canadian Institute of Mining, Metallurgy and Petroleum, Special Volume 54: 211-2249.

[92] Zhou, M-F, Lesher, C. M., Yang, Z. X., Li, J. W. and Sun, M. (2004). Geochemistry and petrogenesis of $270 \mathrm{Ga} \mathrm{Ni-Cu}(\mathrm{PGE})$ sulfide-bearing mafic intrusions in the Huangsthan district, Eastern Xinjiang, Northwestern China: Implication for the tectonic evolution of Central Asian orogenic belt. Chemical Geology, 209: 233-257.

Citation: T. A. Ako et al. (2017). Evaluation of Platinum Group Elements (PGE) Potentials of Ultramafic Rocks of the Paleoproterozoic Nyong Series, Southeast Cameroon, International Journal of Mining Science (IJMS), 3(3), pp.21-39, DOI: http://dx.doi.org/ 10.20431/2454-9460.0303003.

Copyright: (C) 2017 T. A. Ako. This is an open-access article distributed under the terms of the Creative Commons Attribution License, which permits unrestricted use, distribution, and reproduction in any medium, provided the original author and source are credited 